\title{
Analisis Kestabilan Model Matematika Ko-infeksi Virus Influenza A dan Pneumokokus pada Sel Inang
}

\author{
Abdul Faliq Anwar 1, Windarto ${ }^{2}$ \& Cicik Alfiniyah ${ }^{3, *}$ \\ ${ }^{1,2,3}$ Departemen Matematika, Fakultas Sains dan Teknologi, Kampus C \\ Universitas Airlangga, Jl. Mulyorejo, Surabaya \\ *Corresponding author: cicik-a@fst.unair.ac.id
}

\begin{abstract}
Co-infection of influenza A virus and pneumococcus is caused by influenza A virus and pneumococcus bacteria which infected host cell at the same time. The purpose of this thesis is to analyze stability of equilibrium point on mathematical model within-host co-infection of influenza A and pneumococcus. Based on anlytical result of the model there are four quilibrium points, non endemic co-infection equilibrium $\left(E_{0}\right)$, endemic influenza $\mathrm{A}$ virus equilibrium $\left(E_{1}\right)$, endemic pneumococcus equilbrium $\left(E_{2}\right)$ and endemic co-infection equilibrium $\left(E_{3}\right)$. By Next Generation Matrix (NGM), we obtain two basic reproduction number, which are basic reproduction number for influenza $\mathrm{A}$ virus $\left(R_{0 \mathrm{v}}\right)$ and basic reproduction number for pneumococcus $\left(R_{0 \mathrm{~b}}\right)$. Existence of equilibrium point and local stability of equilibrium point dependent on basic reproduction number. Non endemic co-infection equilibrium is locally asymtotically stable if $R_{0 \mathrm{v}}<1$ and $R_{0 \mathrm{~b}}<1$; influenza A virus endemic equilibrium is locally asymtotically stable if $R_{0 \mathrm{v}}>1$ and $R_{0 \mathrm{~b}}>1$; pneumococcus endemic equilibrium is locally asymtotically stable if $R_{0 \mathrm{v}}<1$ and $R_{0 \mathrm{~b}}>1$. Meanwhile, the coinfection endemic equilibrium is locally asymtotically stable if $R_{0 \mathrm{v}}>1$ and $R_{0 \mathrm{~b}}>1$. From the numerical simulation result, it was shown that increasing the number of influenza $\mathrm{A}$ virus and pneumococcus made the number of population cell infected by influenza A virus and pneumococcus (co-infection) also increased.
\end{abstract}

Keywords: mathematical model, influenza A virus, pneumococcus, co-infection, stability, host cell.

\section{Pendahuluan}

Influenza adalah penyakit akibat virus RNA (Ribonucleid Acid) dalam kelompok Orthomyxoviridae yang merupakan penyebab penting dalam morbiditas dan mortalitas pada manusia [1]. Virus influenza menyerang hidung, tenggorokan, bronkus hingga paruparu. Virus dapat menyebar dari orang ke orang melalui udara dengan batuk, bersin ataupun melakukan kontak langsung dengan orang yang terinfeksi [2]. Ada empat jenis virus influenza, yaitu A, B, C dan D. Di antara keempat jenis virus influenza tersebut, hanya virus influenza A yang diketahui sebagai penyebab pandemi (wabah penyakit yang terjadi secara luas di seluruh dunia) pada manusia [3].

Streptococcus pneumoniae, atau pneumokokus, adalah bakteri yang ditemukan secara bersamaan dan independen pada akhir abad ke-19 oleh dokter Amerika George Miller Sternberg dan kimiawan Perancis, Louis Pasteur. Pneumokokus umumnya berada di nasofaring (daerah tenggorokan bagian atas yang terletak di belakang hidung) anak-anak kurang dari dua tahun. Pneumokokus dapat menyebabkan berbagai infeksi seperti infeksi 
telinga, sinusitis dan pneumonia, dan penyakit invasif seperti meningitis dan septikemia. Pneumokokus dapat menular dari orang ke orang melalui kontak langsung maupun tetesan pernapasan (misalnya batuk dan bersin) dari orang yang terinfeksi [4].

Dalam tinjauan ekstensif (menjangkau secara luas) influenza dan ko-infeksi bakteri dari abad ke-20, Streptococcus pneumoniae menjadi penyebab paling umum pada ko-infeksi dibandingkan dengan Haemophilus influenzae, Staphylococcus spp. (khususnya $S$. aureus), dan Streptococcus spp lainnya. Di luar ancaman tingginya tingkat ko-infeksi pada pandemi ini, infeksi bakteri juga berkontribusi terhadap sekitar 65.000 kematian akibat infeksi virus influenza setiap tahun di Amerika Serikat [5].

Pandemi yang disebabkan oleh pneumokokus memang relatif jarang terjadi, oleh karena itu tidak banyak data yang tersedia tentang infeksi bakteri pneumokokus daripada jenis pandemi influenza A. Pneumonia merupakan penyebab umum kasus kematian pada orang yang terkena virus influenza A. Sekitar 25\% kasus ko-infeksi ditemukan dari semua kematian yang diakibatkan oleh virus influenza A. Dari sekitar 30\% kasus pneumonia yang melibatkan ko-infeksi bakteri dengan virus didapatkan bahwa streptococcus pneumoniae merupakan penyebab paling umum dari ko-infeksi bakteri dengan virus influenza A [6]. Pada tahun 2013 sebanyak 56.832 kasus penyakit karena pneumonia dan influenza menjadi penyebab utama kematian di Amerika Serikat. Sementara angka kematian menurut usia untuk pneumonia dan influenza meningkat 9\% dari tahun 2012 hingga 2013. Pada tahun 2013, 53.282 orang meninggal akibat pneumonia dan 3.550 orang meninggal karena influenza [7].

Pemodelan matematika telah banyak diterapkan untuk mendeskripsikan permasalahan nyata, termasuk dalam dunia kesehatan yaitu ko-infeksi virus influenza A dan pneumokokus. Banyak peneliti telah berusaha untuk mempelajari ko-infeksi virus influenza A dan pneumokokus. Diantaranya adalah [8] menjelaskan sebuah model untuk mengevaluasi vaksinasi masal terhadap pneumokokus sebagai tindakan pencegahan terhadap pandemi influenza. [9] menjelaskan model matematika postcoinfection influenza A virus dan Streptococcus pneumoniae, dengan implikasi untuk pneumonia dan penilaian resiko COPD. [10] menjelaskan ko-infeksi virus influenza A dan pneumokokus pada sel inang dengan menerapkan fungsi respon Beddington-DeAngelis pada laju transmisi dari populasi sel yang rentan ke populasi sel yang terinfeksi virus influenza A.

Berdasarkan uraian di atas, penulis tertarik untuk mengkaji kembali model matematika ko-infeksi virus influenza A dan pneumokokus pada sel inang yang merupakan modifikasi dari model yang telah dikembangkan oleh [10]. Modifikasi yang akan dilakukan yaitu mengubah laju transmisi dari populasi sel yang rentan ke populasi sel yang terinfeksi virus influenza A ke dalam bentuk normal incident rate. 


\section{$2 \quad$ Formulasi Model}

Pada bagian ini akan diformulasikan model matematika ko-infeksi virus influenza A dan pneumokokus pada sel inang. Adapun asumsi yang digunakan untuk kontruksi model sebagai berikut :

a. Ko-infeksi pada populasi sel inang disebabkan virus influenza A dan pneumokokus.

b. Sel inang yang terinfeksi melepaskan virion selama masa hidupnya.

c. Populasi pneumokokus bersifat fagosit dengan makrofag alveolar.

d. Laju rekrutmen konstan.

Model matematika ko-infeksi virus influenza A dan pneumokokus pada sel inang dibagi menjadi dua populasi, yaitu populasi sel inang dan populasi patogen. Populasi sel inang terbagi menjadi empat populasi, yaitu populasi sel inang yang rentan dinotasikan dengan $S$, populasi sel inang yang terinfeksi pneumokokus dinotasikan dengan $I_{b}$, populasi sel inang yang terinfeksi virus influenza A dinotasikan dengan $I_{v}$, populasi sel inang yang terinfeksi virus influenza A dan pneumokokus (ko-infeksi) dinotasikan dengan $I_{v b}$. Sedangkan populasi patogen terbagi menjadi dua populasi, yaitu populasi bakteri pneumokokus dinotasikan dengan $B$ dan populasi virus influenza A dinotasikan dengan $V$. Pendefinisian parameter dapat dilihat pada Tabel 1 berikut.

Tabel 1. Pendefinisian Parameter Model

\begin{tabular}{|c|l|}
\hline Notasi & \multicolumn{1}{|c|}{ Keterangan } \\
\hline$A$ & Populasi makrofag alveolar \\
\hline$\Lambda$ & Laju rekrutmen sel inang yang rentan \\
\hline$\beta_{1}$ & Laju infeksi sel inang tiap bakteri \\
\hline$\beta_{2}$ & Laju infeksi sel inang tiap virus influenza A \\
\hline$\beta_{3}$ & Laju infeksi sel yang terinfeksi pneumokokus oleh virus influenza A \\
\hline$\beta_{4}$ & Laju infeksi sel yang terinfeksi virus influenza A oleh pneumokokus \\
\hline$\mu_{1}$ & Laju kematian alami sel yang rentan \\
\hline$\mu_{2}$ & Laju kematian alami sel yang terinfeksi pneumokokus \\
\hline$\mu_{3}$ & Laju kematian alami sel yang terinfeksi virus influenza A \\
\hline$\mu_{4}$ & Laju kematian alami sel yang terkena ko-infeksi \\
\hline$\tau_{1}$ & Laju pembentukan oleh sel yang terinfeksi pneumokokus \\
\hline$\tau_{2}$ & Laju pembentukan oleh sel yang terinfeksi virus influenza A \\
\hline$\tau_{3}$ & Laju pembentukan oleh sel yang tekena ko-infeksi \\
\hline$n_{1}$ & $\begin{array}{l}\text { Jumlah infeksi partikel pneumokokus yang dibebaskan dari lisis sel yang } \\
\text { terinfeksi pneumokokus }\end{array}$ \\
\hline$n_{2}$ & $\begin{array}{l}\text { Jumlah infeksi partikel virus influenza A yang dibebaskan dari lisis sel } \\
\text { yang terinfeksi virus influenza A }\end{array}$ \\
\hline$n_{3}$ & $\begin{array}{l}\text { Jumlah infeksi partikel ko-infeksi yang dibebaskan dari lisis sel yang } \\
\text { terkena ko-infeksi }\end{array}$ \\
\hline
\end{tabular}




\begin{tabular}{|c|l|}
\hline Notasi & \multicolumn{1}{c|}{ Keterangan } \\
\hline$\alpha_{1}$ & $\begin{array}{l}\text { Laju kehilangan pneumokokus karena interaksi sel sehat dengan virus } \\
\text { influenza A }\end{array}$ \\
\hline$\alpha_{2}$ & $\begin{array}{l}\text { Laju kehilangan virus influenza A karena interaksi sel sehat dengan } \\
\text { pneumokokus }\end{array}$ \\
\hline$\delta_{1}$ & Laju kematian oleh racun yang disebabkan pneumokokus \\
\hline$\delta_{2}$ & Laju kematian oleh racun yang disebabkan virus influenza A \\
\hline$r$ & Laju pertumbuhan maksimum pneumokokus \\
\hline$K$ & Carrying capacity \\
\hline$\gamma$ & Laju kematian bakteri karena fagositosis \\
\hline$m$ & $\begin{array}{l}\text { Jumlah maksimal bakteri yang dapat ditangkap makrofag alveolar dalam } \\
\text { satuan waktu } t\end{array}$ \\
\hline$h$ & Waktu penanganan untuk makrofag alveolar \\
\hline
\end{tabular}

Model yang dikembangkan oleh Mbabazi dkk. (2018) menggunakan respon BeddingtonDeAngelis untuk laju transmisi dari populasi sel yang rentan ke populasi sel yang terinfeksi virus influenza A. Sehingga modifikasi yang dilakukan yaitu mengubah respon Beddington-DeAngelis ke dalam bentuk normal incident rate. Berdasarkan asumsi dan pendefinisian parameter serta variabel dapat dibentuk diagram transmisi penyebaran koinfeksi virus influenza A dan pneumokokus pada sel inang yang disajikan pada Gambar 2.1 sebagai berikut.

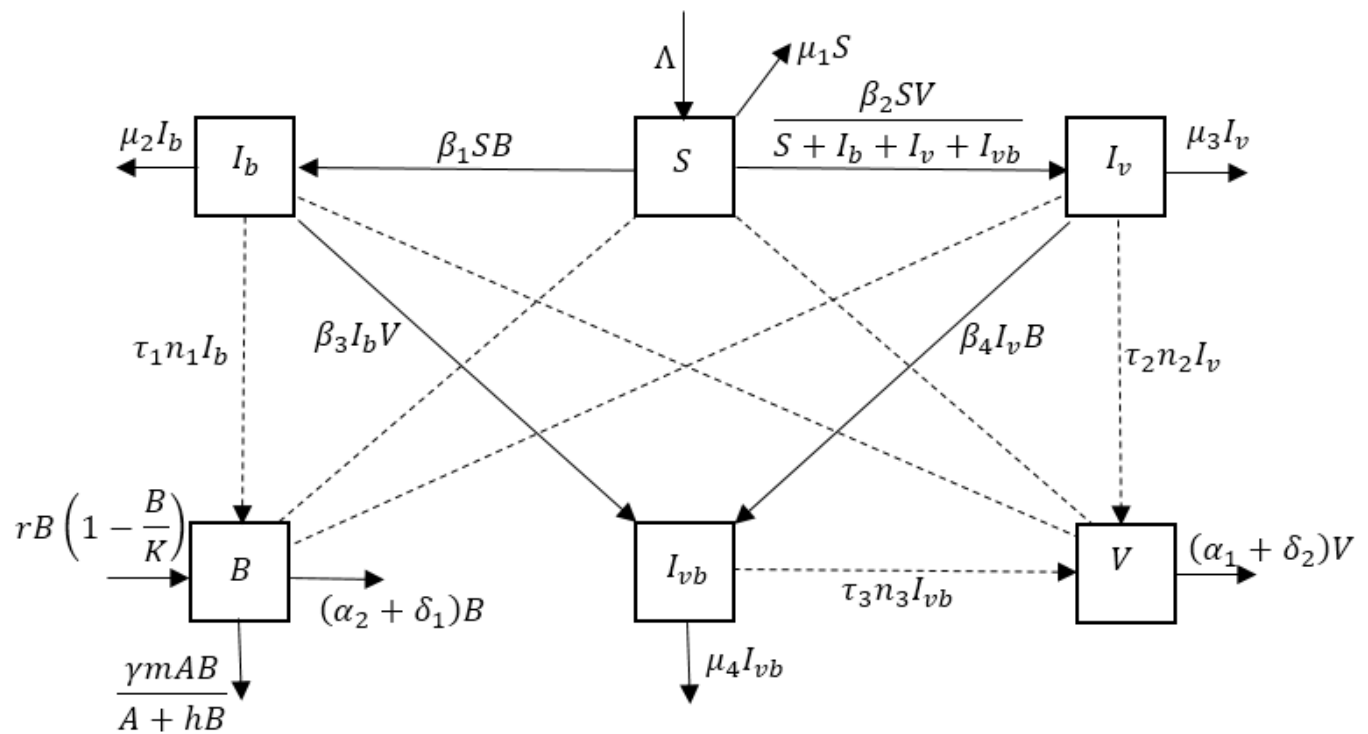

Gambar 1. Diagram Transmisi Model. 
Dari diagram transmisi pada Gambar 1 dapat diformulasikan model sebagai berikut:

$$
\begin{aligned}
& \dot{S}=\Lambda-\frac{\beta_{2} S V}{S+I_{b}+I_{v}+I_{v b}}-\beta_{1} S B-\mu_{1} S, \\
& \dot{I}_{b}=\beta_{1} S B-\left(\mu_{2}+\beta_{3} V\right) I_{b}, \\
& \dot{I}_{v}=\frac{\beta_{2} S V}{S+I_{b}+I_{v}+I_{v b}}-\left(\beta_{4} B+\mu_{3}\right) I_{v}, \\
& \dot{I}_{v b}=\beta_{3} I_{b} V+\beta_{4} I_{v} B-\mu_{4} I_{v b}, \\
& \dot{B}=r B\left(1-\frac{B}{K}\right)+\tau_{1} n_{1} I_{b}-\frac{\gamma m A B}{A+h B}-\left(\alpha_{2}+\delta_{1}\right) B, \\
& \dot{V}=\tau_{2} n_{2} I_{v}+\tau_{3} n_{3} I_{v b}-\left(\alpha_{1}+\delta_{2}\right) V,
\end{aligned}
$$

dengan $S, I_{b}, I_{v}, I_{v b}, B, V \geq 0$. dan semua parameter bernilai positif.

Persamaan (1.1a) menyatakan laju perubahan populasi sel inang sehat tetapi rentan tiap satuan waktu. Populasi sel inang sehat tetapi rentan bertambah karena adanya laju rekutmen sel inang yang sehat, berkurang karena adanya interaksi antara sel inang sehat tetapi rentan dengan virus influenza A, berkurang karena adanya interaksi antara sel inang sehat tetapi rentan dengan pneumokokus dan berkurang karena adanya kematian alami pada sel inang sehat tetapi rentan.

Persamaan (1.1b) menyatakan laju perubahan populasi sel yang terinfeksi pneumokokus tiap satuan waktu. Populasi sel yang terinfeksi pneumokokus bertambah karena adanya interaksi antara sel inang sehat tetapi rentan dengan pneumokokus, berkurang karena adanya kematian alami sel yang terinfeksi pneumokokus dan berkurang karena adanya interaksi antara sel yang terinfeksi pneumokokus dengan virus influenza A.

Persamaan (1.1c) menyatakan laju perubahan populasi sel yang terinfeksi virus influenza A tiap satuan waktu. Populasi sel yang terinfeksi virus influenza A bertambah karena adanya interaksi antara sel inang sehat tetapi rentan dengan virus influenza A, berkurang karena adanya interaksi antara sel terinfeksi virus influenza A dengan pneumokokus dan berkurang karena adanya kematian alami sel yang terinfeksi virus influenza A.

Persamaan (1.1d) menyatakan laju perubahan populasi sel yang terkena ko-infeksi. Populasi sel yang terkena ko-infeksi bertambah karena adanya interaksi antara sel yang terinfeksi pneumokokus dengan virus influenza A, bertambah karena adanya interaksi antara sel yang terinfeksi virus influenza A dengan pneumokokus dan berkurang karena adanya kematian alami sel yang terkena ko-infeksi.

Persamaan (1.1e) menyatakan laju perubahan populasi bakteri pneumokokus tiap satuan waktu. Populasi bakteri pneumokokus bertambah secara logistik, bertambah karena 
adanya pelepasan oleh sel yang terinfeksi pneumokokus, berkurang karena adanya rasio ketergantungan (fagositosis), berkurang karena adanya kehilangan virus influenza A disebabkan interaksi sel sehat dengan pneumokokus dan berkurang karena adanya kematian beracun yang disebabkan pneumokokus.

Persamaan (1.1f) menyatakan populasi laju perubahan virus influenza A tiap satuan waktu. Populasi virus influenza A bertambah karena adanya pelepasan oleh sel yang terinfeksi virus influenza A, bertambah karena adanya pelepasan oleh sel yang terkena ko-infeksi, berkurang karena adanya kehilangan pneumokokus disebabkan interaksi sel sehat dengan virus influenza A dan berkurang karena adanya kematian beracun yang disebabkan virus influenza A.

\section{$3 \quad$ Titik Setimbang Model}

Model matematika ko-infeksi virus influenza A dan pneumokokus pada sel inang memiliki empat titik setimbang, yaitu titik setimbang non endemik ko-infeksi $\left(E_{0}\right)$, titik setimbang endemik virus influenza A $\left(E_{1}\right)$, titik setimbang endemik pneumokokus $\left(E_{2}\right)$ dan titik setimbang endemik ko-infeksi $\left(E_{3}\right)$. Titik setimbang non endemik dari model tersebut adalah $E_{0}=\left(S, I_{b}, I_{v}, I_{v b}, B, V\right)=\left(\frac{\Lambda}{\mu_{1}}, 0,0,0,0,0\right)$.

Selanjutnya, dari titik setimbang non endemik $E_{0}$ dengan menggunakan metode Next Generation Matrix (NGM) [11] sehingga diperoleh dua bilangan reproduksi dasar yaitu, bilangan reproduksi dasar virus influenza $\mathrm{A}\left(R_{0 v}\right)$ dan bilangan reproduksi dasar pneumokokus $\left(R_{0 b}\right)$ sebagai berikut:

$$
\begin{gathered}
R_{0 v}=\frac{\beta_{2} \tau_{2} n_{2}}{\mu_{3}\left(\alpha_{1}+\delta_{2}\right)}, \\
R_{0 b}=\frac{\beta_{1} \Lambda \tau_{1} n_{1}}{\mu_{1} \mu_{2}\left(\alpha_{2}+\delta_{1}+\gamma m-r\right)} .
\end{gathered}
$$

Dari hasil perhitungan diperoleh titik setimbang endemik dari model tersebut adalah sebagai berikut:

1. Titik setimbang endemik virus influenza $\mathrm{A}\left(E_{1}\right)$

$$
E_{1}=\left(S, I_{b}, I_{v}, I_{v b}, B, V\right)=\left(S^{v}, 0, I_{v}^{v}, 0,0, V^{v}\right)
$$

dengan

$$
S^{v}=\frac{\mu_{3}\left(\alpha_{1}+\delta_{2}\right)^{2} V^{*}}{\tau_{2} n_{2}\left(\tau_{2} n_{2} \beta_{2}-\mu_{3}\left(\alpha_{1}+\delta_{2}\right)\right)},
$$


$I_{v}^{v}=\frac{\left(\alpha_{1}+\delta_{2}\right) V^{*}}{\tau_{2} n_{2}}$

$V^{v}=V^{*}$,

dengan

$V^{*}=\frac{\Lambda \tau_{2} n_{2}\left(\tau_{2} n_{2} \beta_{2}-\mu_{3}\left(\alpha_{1}+\delta_{2}\right)\right)}{\mu_{3}\left(\alpha_{1}+\delta_{2}\right)\left(\tau_{2} n_{2} \beta_{2}-\mu_{3}\left(\alpha_{1}+\delta_{2}\right)+\mu_{1}\left(\alpha_{1}+\delta_{2}\right)\right)}$.

Berdasarkan uraian diatas, titik setimbang endemik virus influenza A $\left(E_{1}\right)$ akan eksis atau ada jika memenuhi syarat $\tau_{2} n_{2} \beta_{2}-\mu_{3}\left(\alpha_{1}+\delta_{2}\right)>0 \Leftrightarrow \frac{\tau_{2} n_{2} \beta_{2}}{\mu_{3}\left(\alpha_{1}+\delta_{2}\right)}>1 \Leftrightarrow$ $R_{0 v}>1$.

2. Titik setimbang endemik pneumokokus $\left(E_{2}\right)$

$$
E_{2}=\left(S, I_{b}, I_{v}, I_{v b}, B, V\right)=\left(S^{b}, I_{b}^{b}, 0,0, B^{b}, 0\right)
$$

dengan

$S^{b}=\frac{\Lambda}{\left(\beta_{1} B^{*}+\mu_{1}\right)}$,

$I_{b}^{b}=\frac{\beta_{1} \Lambda B^{*}}{\mu_{2}\left(\beta_{1} B^{*}+\mu_{1}\right)}$

$B^{b}=B^{*}$,

dengan $B^{*}$ merupakan persamaan polinomial pangkat tiga sebagai berikut

$B^{* 3}+a_{0} B^{* 2}+a_{1} B^{*}+a_{2}=0$,

dengan

$a_{0}=\frac{\left(r \mu_{2} \beta_{1} A+r \mu_{1} \mu_{2} h+\mu_{2} \beta_{1} \alpha_{2} K h+\mu_{2} \beta_{1} \delta_{1} K h-r \mu_{2} K \beta_{1} h\right)}{r \mu_{2} \beta_{1} h}$,

$a_{1}=\left(r \mu_{1} \mu_{2} A+\mu_{2} \beta_{1} \gamma m A K+\mu_{2} \beta_{1} \alpha_{2} K A+\mu_{1} \mu_{2} \alpha_{2} K h+\mu_{2} \beta_{1} \delta_{1} K A+\mu_{1} \mu_{2} \delta_{1} K h\right.$

$\left.-r \mu_{2} K \beta_{1} A-r \mu_{1} \mu_{2} K h-\beta_{1} \Lambda \tau_{1} n_{1} K h\right) / r \mu_{2} \beta_{1} h$,

$a_{2}=\frac{\left(\mu_{1} \mu_{2} \gamma m A K+\mu_{1} \mu_{2} \alpha_{2} K A+\mu_{1} \mu_{2} \delta_{1} K A-r \mu_{1} \mu_{2} K A-\beta_{1} \Lambda \tau_{1} n_{1} K A\right)}{r \mu_{2} \beta_{1} h}$.

Berdasarkan uraian diatas, titik setimbang endemik pneumokokus $\left(E_{2}\right)$ bergantung pada $B^{*}$ yang merupakan persamaan polinomial pangkat tiga, sehingga perlu diselidiki apakah persamaan tersebut memiliki akar bilangan real positif. Persamaan di atas akan memiliki satu akar bilangan real positif jika memenuhi kondisi $x_{1} x_{2} x_{3}>0$ dengan $x_{1}, x_{2}, x_{3}$ merupakan akar-akar persamaan di atas. Dengan sifat persamaan akar pangkat tiga diperoleh $x_{1} x_{2} x_{3}=-\frac{d}{a}$. Sehingga agar persamaan di atas mempunyai satu akar bilangan real positif maka 
$-d>0$. Sehingga didapatkan titik setimbang $E_{2}$ eksis jika $\frac{\beta_{1} \Lambda \tau_{1} n_{1}}{\left(\gamma m+\alpha_{2} K A+\delta_{1}-r\right) \mu_{1} \mu_{2}}>$ $1 \Leftrightarrow R_{0 b}>1$.

3. Titik setimbang ko-infeksi $\left(E_{3}\right)$

$$
E_{3}=\left(S, I_{b}, I_{v}, I_{v b}, B, V\right)=\left(S^{v b}, I_{b}^{v b}, I_{v}^{v b}, I_{v b}^{v b}, B^{v b}, V^{v b}\right)
$$

dengan

$$
\begin{aligned}
& S^{v b}=b_{0} S^{* 2}+b_{1} S^{*}+b_{2}=0, \\
& I_{b}^{v b}=\frac{\beta_{1} S^{*} B^{*}}{\left(\mu_{2}+\beta_{3} V^{*}\right)^{\prime}} \\
& I_{v}^{v b}=c_{0} I_{v}{ }^{* 2}+c_{1} I_{v}{ }^{*}+c_{2}=0, \\
& I_{v b}^{v b}=\frac{\beta_{3} I_{b}{ }^{*} V^{*}+\beta_{4} I_{v}{ }^{*} B^{*}}{\mu_{4}}, \\
& B^{v b}=d_{0} B^{* 2}+d_{1} B^{*}+d_{2}=0, \\
& V^{v b}=\frac{\tau_{2} n_{2} I_{v}{ }^{*}+\tau_{3} n_{3} I_{v b}{ }^{*}}{\left(\alpha_{1}+\delta_{2}\right)},
\end{aligned}
$$

dengan

$$
\begin{aligned}
& b_{0}=\left(\beta_{1} B^{*}+\mu_{1}\right), \\
& b_{1}=\left(\beta_{2} V^{*}+\beta_{1} B^{*} P+\mu_{1} P-\Lambda\right), \\
& b_{2}=-\Lambda P, P=I_{b}{ }^{*}+I_{v}{ }^{*}+I_{v b}{ }^{*} \\
& c_{0}=\left(\beta_{4} B^{*}+\mu_{3}\right), \\
& c_{1}=\left(\beta_{4} B^{*}+\mu_{3}\right) Q, \\
& c_{2}=-\beta_{2} S^{*} V^{*}, Q=S^{*}+I_{b}{ }^{*}+I_{v b}{ }^{*} \\
& d_{0}=r h\left(1-\frac{1}{K}\right), \\
& d_{1}=\left(r A\left(1-\frac{1}{K}\right)+h \tau_{1} n_{1}\left(\frac{\beta_{1} S^{*}}{\left(\mu_{2}+\beta_{3} V^{*}\right)}\right)-h\left(\alpha_{2}+\delta_{1}\right)\right), \\
& d_{2}=\left(A \tau_{1} n_{1}\left(\frac{\beta_{1} S^{*}}{\left(\mu_{2}+\beta_{3} V^{*}\right)}\right)-\gamma m A-A\left(\alpha_{2}+\delta_{1}\right)\right) .
\end{aligned}
$$

Karena perhitungan secara analitik sulit untuk dilakukan. Maka dengan menggunakan perhitungan numerik titik setimbang endemik ko-infeksi diduga eksis jika $R_{0 v}>1$ dan $R_{0 b}>1$. 


\section{$4 \quad$ Kestabilan Lokal Titik Setimbang}

Pada bagian ini akan dilakukan analisis kestabilan lokal pada kedua titik setimbang model, yaitu titik setimbang non endemik ko-infeksi $\left(E_{0}\right)$ dan titik setimbang endemik virus influenza A $\left(E_{1}\right)$, titik setimbang endemik pneumokokus $\left(E_{2}\right)$ dan titik setimbang endemik ko-infeksi $\left(E_{3}\right)$.

\subsection{Kestabilan Lokal Titik Setimbang Non Endemik}

Analisis kestabilan lokal titik setimbang non endemik diawali dengan mensubstitusikan nilai titik setimbang non endemik $E_{0}=\left(S, I_{b}, I_{v}, I_{v b}, B, V\right)=\left(\frac{\Lambda}{\mu_{1}}, 0,0,0,0,0\right)$ ke dalam matriks Jacobian, dengan demikian diperoleh:

$$
J_{E_{0}}=\left(\begin{array}{cccccc}
-\mu_{1} & 0 & 0 & 0 & -\beta_{1} \frac{\Lambda}{\mu_{1}} & -\beta_{2} \\
0 & -\mu_{2} & 0 & 0 & \beta_{1} \frac{\Lambda}{\mu_{1}} & 0 \\
0 & 0 & -\mu_{3} & 0 & 0 & \beta_{2} \\
0 & 0 & 0 & -\mu_{4} & 0 & 0 \\
0 & \tau_{1} n_{1} & 0 & 0 & -D_{1} & 0 \\
0 & 0 & \tau_{2} n_{2} & \tau_{3} n_{3} & 0 & -D_{2}
\end{array}\right)
$$

dengan $D_{1}=\alpha_{2}+\delta_{1}+\gamma m-r$ dan $D_{2}=\alpha_{1}+\delta_{2}$.

Berdasarkan matriks Jacobian $J_{E_{0}}$, dapat dibentuk persamaan karakteristik sebagai berikut:

$$
\operatorname{det}\left(\begin{array}{cccccc}
\lambda+\mu_{1} & 0 & 0 & 0 & \beta_{1} \frac{\Lambda}{\mu_{1}} & \beta_{2} \\
0 & \lambda+\mu_{2} & 0 & 0 & -\beta_{1} \frac{\Lambda}{\mu_{1}} & 0 \\
0 & 0 & \lambda+\mu_{3} & 0 & 0 & -\beta_{2} \\
0 & 0 & 0 & \lambda+\mu_{4} & 0 & 0 \\
0 & -\tau_{1} n_{1} & 0 & 0 & \lambda+D_{1} & 0 \\
0 & 0 & -\tau_{2} n_{2} & -\tau_{3} n_{3} & 0 & \lambda+D_{2}
\end{array}\right)=0
$$

dengan demikian diperoleh bentuk yang ekivalen sebagai berikut:

$\left(\lambda+\mu_{1}\right)\left(\lambda+\mu_{4}\right)\left[\lambda^{4}+e_{0} \lambda^{3}+e_{1} \lambda^{2}+e_{2} \lambda+e_{3}\right]=0$

dengan 


$$
\begin{aligned}
& e_{0}=\left(\left(D_{2}+\mu_{3}\right)+\left(D_{1}+\mu_{2}\right)\right), \\
& e_{1}=\left(D_{2} \mu_{3}-\beta_{2} \tau_{2} n_{2}\right)+\left(D_{2}+\mu_{3}\right)\left(D_{1}+\mu_{2}\right)+\left(D_{1} \mu_{2}-\beta_{1} \frac{\Lambda}{\mu_{1}} \tau_{1} n_{1}\right), \\
& e_{2}=\left(\left(D_{2} \mu_{3}-\beta_{2} \tau_{2} n_{2}\right)\left(D_{1}+\mu_{2}\right)+\left(D_{2}+\mu_{3}\right)\left(D_{1} \mu_{2}-\beta_{1} \frac{\Lambda}{\mu_{1}} \tau_{1} n_{1}\right)\right), \\
& e_{3}=\left(D_{2} \mu_{3}-\beta_{2} \tau_{2} n_{2}\right)\left(D_{1} \mu_{2}-\beta_{1} \frac{\Lambda}{\mu_{1}} \tau_{1} n_{1}\right) .
\end{aligned}
$$

Berdasarkan persamaan (2), diperoleh nilai eigen $\lambda_{1}=-\mu_{1}, \lambda_{2}=-\mu_{4}$, dan sisanya adalah akar-akar dari persamaan berikut.

$\lambda^{4}+e_{0} \lambda^{3}+e_{1} \lambda^{2}+e_{2} \lambda+e_{3}$

Titik setimbang non endemik akan stabil asimtotis jika dan hanya jika persamaan karakteristik (1) memiliki akar-akar bagian real negatif. Jelas bahwa $\lambda_{1}$ dan $\lambda_{2}$ bernilai negatif karena semua parameter seperti yang telah dijelaskan bernilai positif. Kemudian akan ditentukan persamaan (2) memiliki akar-akar bagian real negatif, yaitu dengan menggunakan kriteria Routh-Hurwitz. Berdasarkan kriteria Routh-Hurwitz, titik setimbang non endemik akan stabil asimtotis jika dan hanya jika:

$$
\begin{aligned}
& R_{1}=\frac{r}{\left(\alpha_{1}+\delta_{2}+\mu_{3}+\alpha_{2}+\delta_{1}+\gamma m+\mu_{2}\right)}<1, \\
& R_{2}=\frac{\beta_{2} \tau_{2} n_{2}+\beta_{1} \frac{\Lambda}{\mu_{1}} \tau_{1} n_{1}}{F_{2} \mu_{3}+\left(F_{2}+\mu_{3}\right)\left(F_{1}+\mu_{2}\right)+F_{1} \mu_{2}}<1, \\
& R_{3}=\frac{\beta_{2} \tau_{2} n_{2}\left(F_{1}+\mu_{2}\right)+\beta_{1} \frac{\Lambda}{\mu_{1}} \tau_{1} n_{1}\left(F_{2}+\mu_{3}\right)}{F_{2} \mu_{3}\left(F_{1}+\mu_{2}\right)+F_{1} \mu_{2}\left(F_{2}+\mu_{3}\right)}<1, \\
& R_{0 b}=\frac{\beta_{1} \Lambda \tau_{1} n_{1}}{\left(\alpha_{2}+\delta_{1}+\gamma m-r\right) \mu_{1} \mu_{2}}<1, \\
& R_{0 v}=\frac{\beta_{2} \tau_{2} n_{2}}{\left(\alpha_{1}+\delta_{2}\right) \mu_{3}}<1, \\
& \frac{e_{0}^{2} e_{3}+e_{2}^{2}}{e_{0} e_{1} e_{2}}<1 .
\end{aligned}
$$

Hal ini menunjukkan bahwa jika syarat terpenuhi maka tidak ada penyebaran penyakit.

\subsection{Kestabilan Lokal Titik Setimbang Endemik Virus Influenza A}

Langkah pertama untuk menentukan kestabilan titik setimbang endemik virus influenza A yaitu dengan mensubstitusikan titik setimbang endemik $E_{1}=\left(S, I_{b}, I_{v}, I_{v b}, B, V\right)=$ $\left(S^{v}, 0, I_{v}^{v}, 0,0, V^{v}\right)$ pada matriks Jacobian, sehingga diperoleh : 


$$
J_{E_{1}}=\left(\begin{array}{cccccc}
-F_{1}+F_{2}-\mu_{1} & F_{2} & F_{2} & F_{2} & -F_{3} & -F_{7} \\
0 & -\mu_{2}-\beta_{3} V & 0 & 0 & F_{3} & 0 \\
F_{1}-F_{2} & -F_{2} & -F_{2}-\mu_{3} & -F_{2} & -F_{4} & F_{7} \\
0 & \beta_{3} V & 0 & -\mu_{4} & F_{4} & 0 \\
0 & \tau_{1} n_{1} & 0 & 0 & -F_{5} & 0 \\
0 & 0 & \tau_{2} n_{2} & \tau_{3} n_{3} & 0 & -F_{6}
\end{array}\right)
$$

dengan

$$
\begin{aligned}
& F_{1}=\frac{\beta_{2} V^{*}}{\left(\frac{\mu_{3}\left(\alpha_{1}+\delta_{2}\right)^{2} V^{*}}{\tau_{2} n_{2}\left(\tau_{2} n_{2} \beta_{2}-\mu_{3}\left(\alpha_{1}+\delta_{2}\right)\right)}\right)+\left(\frac{\left(\alpha_{1}+\delta_{2}\right) V^{*}}{\tau_{2} n_{2}}\right)}, \\
& F_{2}=\frac{\beta_{2}\left(\frac{\mu_{3}\left(\alpha_{1}+\delta_{2}\right)^{2} V^{*}}{\tau_{2} n_{2}\left(\tau_{2} n_{2} \beta_{2}-\mu_{3}\left(\alpha_{1}+\delta_{2}\right)\right)}\right) V^{*}}{\left(\left(\frac{\mu_{3}\left(\alpha_{1}+\delta_{2}\right)^{2} V^{*}}{\tau_{2} n_{2}\left(\tau_{2} n_{2} \beta_{2}-\mu_{3}\left(\alpha_{1}+\delta_{2}\right)\right)}\right)+\left(\frac{\left(\alpha_{1}+\delta_{2}\right) V^{*}}{\tau_{2} n_{2}}\right)\right)^{2}}, \\
& F_{3}=\beta_{1}\left(\frac{\mu_{3}\left(\alpha_{1}+\delta_{2}\right)^{2} V^{*}}{\tau_{2} n_{2}\left(\tau_{2} n_{2} \beta_{2}-\mu_{3}\left(\alpha_{1}+\delta_{2}\right)\right)}\right) \\
& F_{4}=\beta_{3}\left(\frac{\left(\alpha_{1}+\delta_{2}\right) V^{*}}{\tau_{2} n_{2}}\right), \\
& F_{5}=\gamma m+\alpha_{2}+\delta_{1}-r, \\
& F_{6}=\left(\alpha_{1}+\delta_{2}\right), \\
& F_{7}=\frac{\beta_{2}\left(\frac{\mu_{3}\left(\alpha_{1}+\delta_{2}\right)^{2} V^{*}}{\tau_{2} n_{2}\left(\tau_{2} n_{2} \beta_{2}-\mu_{3}\left(\alpha_{1}+\delta_{2}\right)\right)}\right)}{\left(\frac{\mu_{3}\left(\alpha_{1}+\delta_{2}\right)^{2} V^{*}}{\tau_{2} n_{2}\left(\tau_{2} n_{2} \beta_{2}-\mu_{3}\left(\alpha_{1}+\delta_{2}\right)\right)}\right)+\left(\frac{\left(\alpha_{1}+\delta_{2}\right) V^{*}}{\tau_{2} n_{2}}\right)} .
\end{aligned}
$$

Dalam menentukan akar-akar persamaan karakteristik dari $\operatorname{det}\left(\lambda I-J_{E_{1}}\right)=0$ sulit dilakukan secara analitik karena persamaan yang dihasilkan rumit dan bergantung pada variabel $V^{*}$, maka dilakukan analisis secara numerik dengan menggunakan bidang fase.

Simulasi ini dilakukan dengan memberi nilai parameter dan tiga nilai awal yang berbeda untuk masing-masing subpopulasi $S, I_{b}, I_{v}, I_{v b}, B, V$. Hal ini bertujuan untuk mengetahui kestabilan solusi dari masing-masing nilai awal dan parameter yang digunakan. Simulasi ini dilakukan untuk waktu $t=0$ sampai dengan $t=50$ hari. Nilai awal dan parameter untuk simulasi bidang fase pada model matematika ko-infeksi virus influenza A dan pneumokokus pada sel inang disajikan pada Tabel 2.2. dan 2.3. 
Tabel 2. Nilai Awal Bidang Fase Titik Setimbang Endemik $E_{1}$

\begin{tabular}{|c|c|c|c|}
\hline Nilai Awal & 1 & 2 & 3 \\
\hline$S$ & $4 \times 10^{8}$ & $5 \times 10^{8}$ & $2.6 \times 10^{8}$ \\
\hline$I_{b}$ & $10^{5}$ & $9 \times 10^{7}$ & $9 \times 10^{6}$ \\
\hline$I_{v}$ & $10^{7}$ & $9 \times 10^{7}$ & $5 \times 10^{7}$ \\
\hline$I_{v b}$ & $10^{3}$ & $9 \times 10^{6}$ & $9 \times 10^{7}$ \\
\hline$B$ & $1.6 \times 10^{3}$ & $1.7 \times 10^{3}$ & $1.2 \times 10^{3}$ \\
\hline$V$ & $10^{12}$ & $9 \times 10^{12}$ & $5 \times 10^{12}$ \\
\hline Warna & Biru & Hijau & Merah \\
\hline
\end{tabular}

Tabel 3. Nilai Parameter Bidang Fase Titik Setimbang Endemik $E_{1}$

\begin{tabular}{|c|c|c|c|}
\hline Parameter & Nilai & Satuan & Sumber \\
\hline$\Lambda$ & $6.25 \times 10^{7}$ & sel.hari ${ }^{-1}$ & Mbabazi dkk. \\
\hline$\beta_{1}$ & $1.2 \times 10^{-5}$ & sel $^{-1} \cdot$ hari $^{-1}$ & Mbabazi dkk. \\
\hline$\beta_{2}$ & $2.7 \times 10^{-5}$ & sel $^{-1} \cdot$ hari $^{-1}$ & Mbabazi dkk. \\
\hline$\beta_{3}$ & $7.3 \times 10^{-8}$ & sel $^{-1} \cdot$ hari $^{-1}$ & Mbabazi dkk. \\
\hline$\beta_{4}$ & $4.1 \times 10^{-6}$ & sel $^{-1} \cdot$ hari $^{-1}$ & Mbabazi dkk. \\
\hline$\mu_{1}$ & $6.25 \times 10^{-2}$ & hari $^{-1}$ & Mbabazi dkk. \\
\hline$\mu_{2}$ & $1.34 \times 10^{-5}$ & hari $^{-1}$ & Asumsi \\
\hline$\mu_{3}$ & $8.9 \times 10^{-1}$ & hari $^{-1}$ & Mbabazi dkk. \\
\hline$\mu_{4}$ & $5.2 \times 10^{-2}$ & $h_{a r i}{ }^{-1}$ & Asumsi \\
\hline$\tau_{1}$ & $1.102 \times 10^{-5}$ & hari $^{-1}$ & Asumsi \\
\hline$\tau_{2}$ & $8.6 \times 10^{-1}$ & $h{ }^{-1}$ & Asumsi \\
\hline$\tau_{3}$ & $2.4 \times 10^{-3}$ & hari $^{-1}$ & Asumsi \\
\hline$n_{1}$ & $1 \times 10^{3}$ & hari $^{-1}$ & Mbabazi dkk. \\
\hline$n_{2}$ & $10^{5}$ & hari $^{-1}$ & Asumsi \\
\hline$n_{3}$ & $2.51 \times 10^{1}$ & hari $^{-1}$ & Mbabazi dkk. \\
\hline$\alpha_{1}$ & $3.2 \times 10^{-4}$ & hari $^{-1}$ & Mbabazi dkk. \\
\hline$\alpha_{2}$ & $10^{-3}$ & hari $^{-1}$ & Mbabazi dkk. \\
\hline$\delta_{1}$ & $2 \times 10^{-5}$ & hari $^{-1}$ & Mbabazi dkk. \\
\hline$\delta_{2}$ & 0.5 & hari $^{-1}$ & Mbabazi dkk. \\
\hline$r$ & $2.7 \times 10^{1}$ & $h_{a r i}{ }^{-1}$ & Mbabazi dkk. \\
\hline$K$ & $2.3 \times 10^{8}$ & $\overline{C F U}$ & Mbabazi dkk. \\
\hline$\gamma$ & $8.877 \times 10^{-1}$ & sel $^{-1} \cdot$ hari $^{-1}$ & Mbabazi dkk. \\
\hline$m$ & $10^{11}$ & $(\mathrm{CFU} / \mathrm{ml}) \mathrm{sel}^{-1}$ & Asumsi \\
\hline$h$ & 5 & jam & Mbabazi dkk. \\
\hline$A$ & $10^{5.5}$ & sel & Mbabazi dkk. \\
\hline
\end{tabular}

Hasil simulasi bidang fase pada titik setimbang endemik model ditunjukkan pada Gambar 2 berikut: 


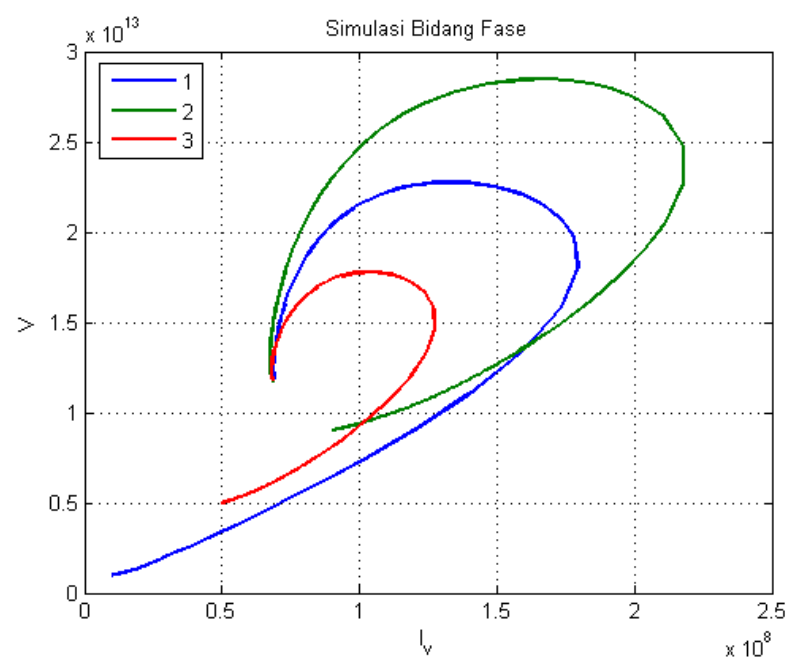

Gambar 2. Simulasi Bidang Fase pada Bidang $I_{v}-V$ untuk $E_{1}$

Gambar 2 merupakan gambar grafik pada ruang dua dimensi dari populasi $I_{v}$ dan $V$ pada model matematika ko-infeksi virus influenza A dan pneumokokus pada sel inang. Pada gambar terlihat bahwa untuk $t$ yang semakin besar maka solusi dari model khususnya $I_{v}$ dan $V$ cenderung menuju ke suatu titik yang sama atau cenderung konvergen ke titik $\left(6.907 \times 10^{7}, 1.187 \times 10^{13}\right)$. Secara keseluruhan dinamika dari setiap subpopulasi pada model matematika ko-infeksi virus influenza A dan pneumokokus pada sel inang bergerak menuju titik setimbang endemik virus influenza A $E_{1}=(1.639 \times$ $\left.10^{7}, 0,6.907 \times 10^{7}, 0,0,1.187 \times 10^{13}\right)$. Nilai $E_{1}$ diperoleh dengan mensubstitusikan nilai parameter pada Tabel 2.3 pada persamaan (2.1a) - (2.1f). Selain itu, berdasarkan nilai parameter yang diberikan pada Tabel 2.3 dapat diperoleh nilai $R_{0 v}>1$ dan $R_{0 b}<$ 1.

Berdasarkan hasil simulasi pada Gambar 2.2 diperoleh hasil bahwa titik setimbang endemik virus influenza A pada model matematika ko-infeksi virus influenza A dan pneumokokus pada sel inang akan cenderung stabil asimtotis lokal jika memenuhi $R_{0 v}>$ 1 dan $R_{0 b}<1$. Hal ini merepresentasikan bahwa jika $R_{0 v}>1$, maka setiap sel yang terinfeksi virus influenza A dapat menularkan penyakit influenza A rata-rata lebih dari satu penderita baru atau dengan kata lain terdapat penyebaran penyakit influenza A. Sedangkan jika $R_{0 b}<1$, maka setiap sel yang terinfeksi bakteri pneumokokus dapat menularkan penyakit pneumokokus rata-rata kurang dari satu penderita baru atau dengan kata lain tidak terjadi penyebaran penyakit pneumokokus. 


\subsection{Kestabilan Lokal Titik Setimbang Endemik Pneumokokus}

Langkah pertama untuk menentukan kestabilan titik setimbang endemik pneumokokus yaitu dengan mensubstitusikan titik setimbang endemik $E_{2}=\left(S, I_{b}, I_{v}, I_{v b}, B, V\right)=$ $\left(S^{b}, I_{b}^{b}, 0,0, B^{b}, 0\right)$ pada matriks Jacobian, sehingga diperoleh :

$$
J_{E_{2}}=\left(\begin{array}{cccccc}
-\beta_{1} B^{*}-\mu_{1} & 0 & 0 & 0 & -H_{1} & -H_{2} \\
\beta_{1} B^{*} & -\mu_{2} & 0 & 0 & H_{1} & -H_{5} \\
0 & 0 & -\beta_{4} B^{*}-\mu_{3} & 0 & 0 & H_{2} \\
0 & 0 & \beta_{4} B^{*} & -\mu_{4} & 0 & H_{5} \\
0 & \tau_{1} n_{1} & 0 & 0 & -H_{3} & 0 \\
0 & 0 & \tau_{2} n_{2} & \tau_{3} n_{3} & 0 & -H_{4}
\end{array}\right)
$$

dengan

$$
\begin{aligned}
& H_{1}=\beta_{1}\left(\frac{\Lambda}{\left(\beta_{1} B^{*}+\mu_{1}\right)}\right), \\
& H_{2}=\frac{\beta_{2}\left(\frac{\Lambda}{\left(\beta_{1} B^{*}+\mu_{1}\right)}\right)}{\left(\frac{\Lambda}{\left(\beta_{1} B^{*}+\mu_{1}\right)}\right)+\left(\frac{\beta_{1} \Lambda B^{*}}{\mu_{2}\left(\beta_{1} B^{*}+\mu_{1}\right)}\right)}, \\
& H_{3}=\frac{2 r B^{*}}{K}+\frac{\gamma m A}{A+h B^{*}}+\frac{\gamma m A h B^{*}}{\left(A+h B^{*}\right)^{2}}+\alpha_{2}+\delta_{1}-r, \\
& H_{4}=\left(\alpha_{1}+\delta_{2}\right), \\
& H_{5}=\beta_{3}\left(\frac{\beta_{1} \Lambda B^{*}}{\mu_{2}\left(\beta_{1} B^{*}+\mu_{1}\right)}\right) .
\end{aligned}
$$

Dalam menentukan akar-akar persamaan karakteristik dari $\operatorname{det}\left(\lambda I-J_{E_{2}}\right)=0$ sulit dilakukan secara analitik karena persamaan yang dihasilkan rumit dan bergantung pada variabel $B^{*}$, maka dilakukan analisis secara numerik dengan menggunakan bidang fase.

Simulasi ini dilakukan dengan memberi nilai parameter dan tiga nilai awal yang berbeda untuk masing-masing subpopulasi $S, I_{b}, I_{v}, I_{v b}, B, V$. Hal ini bertujuan untuk mengetahui kestabilan solusi dari masing-masing nilai awal dan parameter yang digunakan. Simulasi ini dilakukan untuk waktu $t=0$ sampai dengan $t=50$ hari. Nilai awal dan parameter untuk simulasi bidang fase pada model matematika ko-infeksi virus influenza A dan pneumokokus pada sel inang disajikan pada Tabel 4. dan 5. 
Tabel 4. Nilai Awal Bidang Fase Titik Setimbang Endemik $E_{2}$

\begin{tabular}{|c|c|c|c|}
\hline Nilai Awal & 1 & 2 & 3 \\
\hline$S$ & $4 \times 10^{8}$ & $4.5 \times 10^{8}$ & $3.9 \times 10^{8}$ \\
\hline$I_{b}$ & $10^{5}$ & $9 \times 10^{7}$ & $7 \times 10^{8}$ \\
\hline$I_{v}$ & $10^{2}$ & $1.5 \times 10^{2}$ & $0.7 \times 10^{2}$ \\
\hline$I_{v b}$ & $10^{3}$ & $1.5 \times 10^{3}$ & $0.7 \times 10^{3}$ \\
\hline$B$ & $1.6 \times 10^{3}$ & $1.7 \times 10^{8}$ & $1.5 \times 10^{7}$ \\
\hline$V$ & $10^{5}$ & $1.5 \times 10^{5}$ & $0.7 \times 10^{5}$ \\
\hline Warna & Biru & Hijau & Merah \\
\hline
\end{tabular}

Tabel 5. Nilai Parameter Bidang Fase Titik Setimbang Endemik $E_{2}$

\begin{tabular}{|c|c|c|c|}
\hline Parameter & Nilai & Satuan & Sumber \\
\hline$\Lambda$ & $6.25 \times 10^{7}$ & sel.hari ${ }^{-1}$ & Mbabazi dkk. \\
\hline$\beta_{1}$ & $1.2 \times 10^{-5}$ & sel $^{-1} \cdot$ hari $^{-1}$ & Mbabazi dkk. \\
\hline$\beta_{2}$ & $2.7 \times 10^{-5}$ & sel $^{-1} \cdot$ hari $^{-1}$ & Mbabazi dkk. \\
\hline$\beta_{3}$ & $7.3 \times 10^{-8}$ & sel $^{-1} \cdot$ hari $^{-1}$ & Mbabazi dkk. \\
\hline$\beta_{4}$ & $4.1 \times 10^{-6}$ & sel $^{-1} \cdot$ hari $^{-1}$ & Mbabazi dkk. \\
\hline$\mu_{1}$ & $6.25 \times 10^{-3}$ & hari $^{-1}$ & Mbabazi dkk. \\
\hline$\mu_{2}$ & $1.34 \times 10^{-1}$ & hari $^{-1}$ & Asumsi \\
\hline$\mu_{3}$ & $8.9 \times 10^{-1}$ & hari $^{-1}$ & Mbabazi dkk. \\
\hline$\mu_{4}$ & $5.2 \times 10^{-1}$ & hari $^{-1}$ & Asumsi \\
\hline$\tau_{1}$ & $1.102 \times 10^{-5}$ & hari $^{-1}$ & Asumsi \\
\hline$\tau_{2}$ & $8.6 \times 10^{-2}$ & hari $^{-1}$ & Asumsi \\
\hline$\tau_{3}$ & $2.4 \times 10^{-5}$ & hari $^{-1}$ & Asumsi \\
\hline$n_{1}$ & $1 \times 10^{3}$ & hari $^{-1}$ & Mbabazi dkk. \\
\hline$n_{2}$ & $10^{5}$ & hari $^{-1}$ & Asumsi \\
\hline$n_{3}$ & $2.51 \times 10^{1}$ & $h a r i^{-1}$ & Mbabazi dkk. \\
\hline$\alpha_{1}$ & $3.2 \times 10^{-4}$ & hari $^{-1}$ & Mbabazi dkk. \\
\hline$\alpha_{2}$ & $10^{-3}$ & hari $^{-1}$ & Mbabazi dkk. \\
\hline$\delta_{1}$ & $2 \times 10^{-5}$ & hari $^{-1}$ & Mbabazi dkk. \\
\hline$\delta_{2}$ & 0,5 & hari $^{-1}$ & Mbabazi dkk. \\
\hline$r$ & $2.7 \times 10^{1}$ & hari $^{-1}$ & Mbabazi dkk. \\
\hline$K$ & $2.3 \times 10^{8}$ & $C F U$ & Mbabazi dkk. \\
\hline$\gamma$ & $8.877 \times 10^{-1}$ & sel $^{-1} \cdot$ hari $^{-1}$ & Mbabazi dkk. \\
\hline$m$ & 60 & $(C F U / m l) \mathrm{sel}^{-1}$ & Asumsi \\
\hline$h$ & 5 & jam & Mbabazi dkk. \\
\hline$A$ & $10^{5.5}$ & sel & Mbabazi dkk. \\
\hline
\end{tabular}

Hasil simulasi bidang fase pada titik setimbang endemik model ditunjukkan pada Gambar 3 berikut: 


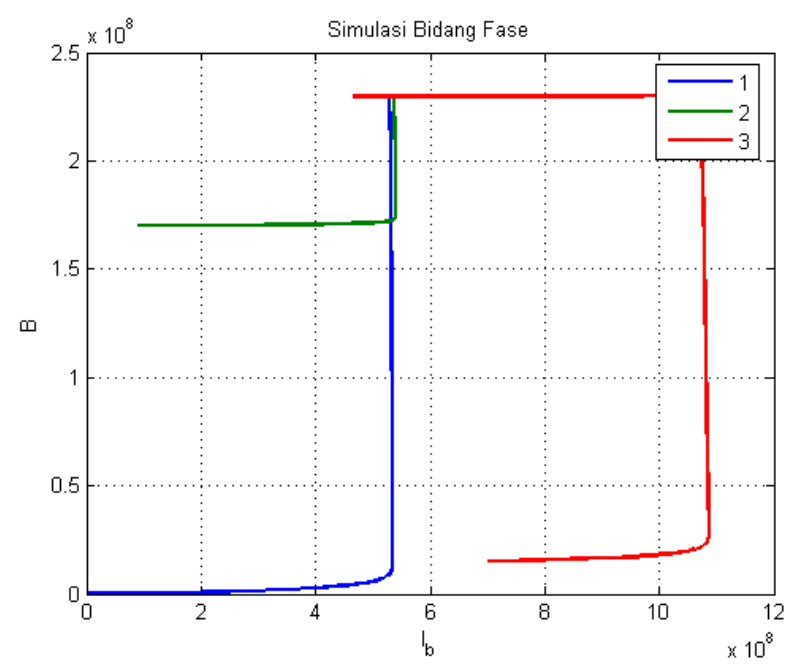

Gambar 3. Simulasi Bidang Fase pada Bidang $I_{b}-B$ untuk $E_{2}$

Gambar 3 merupakan gambar grafik pada ruang dua dimensi dari populasi $I_{b}$ dan $B$ pada model matematik ko-infeksi virus influenza $A$ dan pneumokokus pada sel inang. Pada gambar terlihat bahwa untuk $t$ yang semakin besar maka solusi dari model khususnya $I_{b}$ dan $B$ cenderung menuju ke suatu titik yang sama atau cenderung konvergen ke titik $\left(4.664 \times 10^{8}, 2.301 \times 10^{8}\right)$. Secara keseluruhan dinamika dari setiap subpopulasi pada model matematika ko-infeksi virus influenza A dan pneumokokus pada sel inang bergerak menuju titik setimbang endemik pneumokokus $E_{2}=(22639,4.664 \times$ $\left.10^{8}, 0,0,2.301 \times 10^{8}, 0\right)$. Nilai $E_{2}$ diperoleh dengan mensubstitusikan nilai parameter pada Tabel 2.5 pada persamaan (2.1a) - (2.1f). Selain itu, berdasarkan nilai parameter yang diberikan pada Tabel 2.5 dapat diperoleh nilai $R_{0 v}<1$ dan $R_{0 b}>1$.

Berdasarkan hasil simulasi pada Gambar 2.3 diperoleh hasil bahwa titik setimbang endemik pneumokokus pada model matematika ko-infeksi virus influenza A dan pneumokokus pada sel inang akan cenderung stabil asimtotis lokal jika memenuhi $R_{0 v}<$ 1 dan $R_{0 b}>1$. Hal ini merepresentasikan bahwa jika $R_{0 v}<1$, maka setiap sel yang terinfeksi virus influenza A dapat menularkan penyakit influenza A rata-rata kurang dari satu penderita baru atau dengan kata lain tidak terjadi penyebaran penyakit influenza A. Sedangkan jika $R_{0 b}>1$, maka setiap sel yang terinfeksi bakteri pneumokokus dapat menularkan penyakit pneumokokus rata-rata lebih dari satu penderita baru atau dengan kata lain terjadi penyebaran penyakit pneumokokus. 


\subsection{Kestabilan Lokal Titik Setimbang Endemik Ko-infeksi}

Langkah pertama untuk menentukan kestabilan titik setimbang endemik pneumokokus yaitu dengan mensubstitusikan titik setimbang endemik $E_{3}=\left(S, I_{b}, I_{v}, I_{v b}, B, V\right)=$ $\left(S^{v b}, I_{b}^{v b}, I_{v}^{v b}, I_{v b}^{v b}, B^{v b}, V^{v b}\right)$ pada matriks Jacobian, sehingga diperoleh :

$$
J_{E_{3}}=\left(\begin{array}{cccccc}
-L_{1}+L_{2}-L_{4}-\mu_{1} & L_{2} & L_{2} & L_{2} & -L_{7} & -L_{3} \\
L_{4} & -\mu_{2}-L_{5} & 0 & 0 & L_{7} & -L_{9} \\
L_{1}-L_{2} & -L_{2} & -L_{2}-L_{6}-\mu_{3} & -L_{2} & -L_{8} & L_{3} \\
0 & L_{5} & L_{6} & -\mu_{4} & L_{8} & L_{9} \\
0 & \tau_{1} n_{1} & 0 & 0 & -L_{10} & 0 \\
0 & 0 & \tau_{2} n_{2} & \tau_{3} n_{3} & 0 & -L_{11}
\end{array}\right)
$$

dengan

$L_{1}=\frac{\beta_{2} V^{*}}{S+I_{b}{ }^{*}+I_{v}{ }^{*}+I_{v b}{ }^{*}}$

$L_{2}=\frac{\beta_{2} S^{*} V^{*}}{\left(S^{*}+I_{b}{ }^{*}+I_{v}{ }^{*}+I_{v b}{ }^{2}\right)^{2}}$,

$L_{3}=\frac{\beta_{2} S^{*}}{S^{*}+I_{b}{ }^{*}+I_{v}^{*}+I_{v b}{ }^{*}}$

$L_{4}=\beta_{1} B^{*}$,

$L_{5}=\beta_{3} V^{*}$,

$L_{6}=\beta_{4} B^{*}$,

$L_{7}=\beta_{1} S^{*}$,

$L_{8}=\beta_{4} I_{v}{ }^{*}$,

$L_{9}=\beta_{3} I_{b}{ }^{*}$,

$L_{10}=\frac{2 r B^{*}}{K}+\frac{\gamma m A}{A+h B^{*}}-\frac{\gamma m A h B^{*}}{\left(A+h B^{*}\right)^{2}}+\alpha_{2}+\delta_{1}-r$,

$L_{11}=\alpha_{1}+\delta_{2}$.

Dalam menentukan akar-akar persamaan karakteristik dari $\operatorname{det}\left(\lambda I-J_{E_{3}}\right)=0$ sulit dilakukan secara analitik karena persamaan yang dihasilkan rumit dan bergantung pada variabel $S, I_{b}, I_{v}, I_{v b}, B, V$, maka dilakukan analisis secara numerik dengan menggunakan bidang fase.

Simulasi ini dilakukan dengan memberi nilai parameter dan tiga nilai awal yang berbeda untuk masing-masing subpopulasi $S, I_{b}, I_{v}, I_{v b}, B, V$. Hal ini bertujuan untuk mengetahui kestabilan solusi dari masing-masing nilai awal dan parameter yang digunakan. Simulasi ini dilakukan untuk waktu $t=0$ sampai dengan $t=50$ hari. Nilai awal dan parameter untuk simulasi bidang fase pada model matematika ko-infeksi virus influenza A dan pneumokokus pada sel inang disajikan pada Tabel 6. dan 7. 
Tabel 6. Nilai Awal Bidang Fase Titik Setimbang Endemik $E_{3}$

\begin{tabular}{|c|c|c|c|}
\hline Nilai Awal & 1 & 2 & 3 \\
\hline$S$ & $4 \times 10^{8}$ & $5 \times 10^{8}$ & $2.6 \times 10^{8}$ \\
\hline$I_{b}$ & $10^{5}$ & $3 \times 10^{8}$ & $5 \times 10^{6}$ \\
\hline$I_{v}$ & $10^{2}$ & $1.5 \times 10^{2}$ & $0.3 \times 10^{2}$ \\
\hline$I_{v b}$ & $10^{3}$ & $9 \times 10^{6}$ & $2 \times 10^{8}$ \\
\hline$B$ & $1.6 \times 10^{3}$ & $1.7 \times 10^{3}$ & $1.2 \times 10^{3}$ \\
\hline$V$ & $10^{5}$ & $1.5 \times 10^{5}$ & $0.6 \times 10^{4}$ \\
\hline Warna & Biru & Hijau & Merah \\
\hline
\end{tabular}

Tabel 7. Nilai Parameter Bidang Fase Titik Setimbang Endemik $E_{3}$

\begin{tabular}{|c|c|c|c|}
\hline Parameter & Nilai & Satuan & Sumber \\
\hline$\Lambda$ & $6.25 \times 10^{7}$ & sel.hari ${ }^{-1}$ & Mbabazi dkk. \\
\hline$\beta_{1}$ & $1.2 \times 10^{-5}$ & sel $^{-1} \cdot$ hari $^{-1}$ & Mbabazi dkk. \\
\hline$\beta_{2}$ & $2.7 \times 10^{-5}$ & sel $^{-1} \cdot$ hari $^{-1}$ & Mbabazi dkk. \\
\hline$\beta_{3}$ & $7.3 \times 10^{-8}$ & sel $^{-1} \cdot$ hari $^{-1}$ & Mbabazi dkk. \\
\hline$\beta_{4}$ & $4.1 \times 10^{-6}$ & $\mathrm{sel}^{-1} \cdot \mathrm{hari}^{-1}$ & Mbabazi dkk. \\
\hline$\mu_{1}$ & $6.25 \times 10^{-2}$ & hari $^{-1}$ & Mbabazi dkk. \\
\hline$\mu_{2}$ & $1.34 \times 10^{-5}$ & hari $^{-1}$ & Asumsi \\
\hline$\mu_{3}$ & $8.9 \times 10^{-1}$ & $h_{a r i}{ }^{-1}$ & Mbabazi dkk. \\
\hline$\mu_{4}$ & $5.2 \times 10^{-1}$ & $h_{a r i}{ }^{-1}$ & Asumsi \\
\hline$\tau_{1}$ & $1.102 \times 10^{-5}$ & hari $^{-1}$ & Asumsi \\
\hline$\tau_{2}$ & $8.6 \times 10^{-1}$ & hari $^{-1}$ & Asumsi \\
\hline$\tau_{3}$ & $2.4 \times 10^{-3}$ & $h_{a r i}{ }^{-1}$ & Asumsi \\
\hline$n_{1}$ & $1 \times 10^{3}$ & hari $^{-1}$ & Mbabazi dkk. \\
\hline$n_{2}$ & $10^{5}$ & $\operatorname{hari}^{-1}$ & Asumsi \\
\hline$n_{3}$ & $2.51 \times 10^{1}$ & $h_{a r i}{ }^{-1}$ & Mbabazi dkk. \\
\hline$\alpha_{1}$ & $3.2 \times 10^{-4}$ & $h_{a r i}{ }^{-1}$ & Mbabazi dkk. \\
\hline$\alpha_{2}$ & $10^{-3}$ & $h_{a r i}{ }^{-1}$ & Mbabazi dkk. \\
\hline$\delta_{1}$ & $2 \times 10^{-5}$ & $\operatorname{hari}^{-1}$ & Mbabazi dkk. \\
\hline$\delta_{2}$ & 0,5 & $\operatorname{hari}^{-1}$ & Mbabazi dkk. \\
\hline$r$ & $2.7 \times 10^{1}$ & hari $^{-1}$ & Mbabazi dkk. \\
\hline$K$ & $2.3 \times 10^{8}$ & $C F U$ & Mbabazi dkk. \\
\hline$\gamma$ & $8.877 \times 10^{-1}$ & sel $^{-1} \cdot$ hari $^{-1}$ & Mbabazi dkk. \\
\hline$m$ & 60 & $(C F U / m l) \mathrm{sel}^{-1}$ & Asumsi \\
\hline$h$ & 5 & jam & Mbabazi dkk. \\
\hline$A$ & $10^{5.5}$ & sel & Mbabazi dkk. \\
\hline
\end{tabular}

Hasil simulasi bidang fase pada titik setimbang endemik model Gambar 4 berikut: 


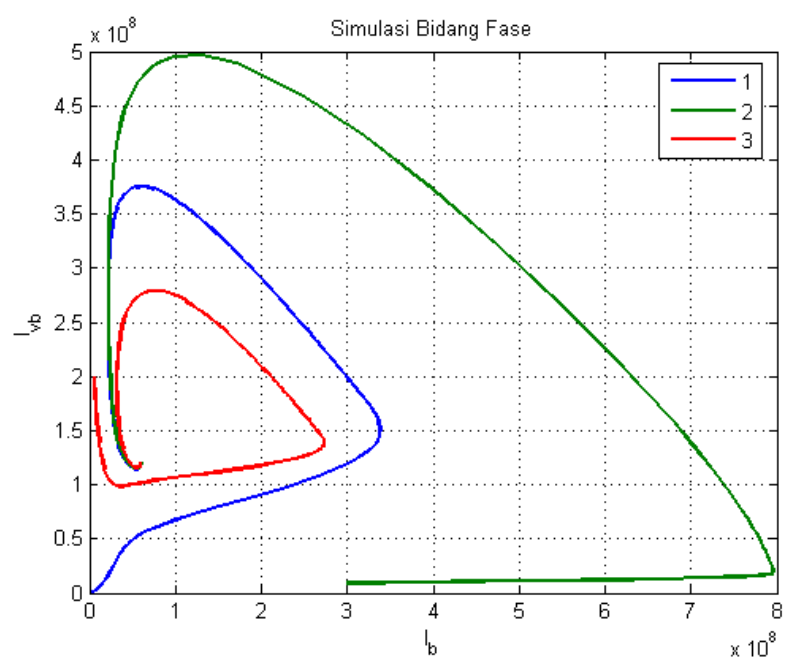

Gambar 4. Simulasi Bidang Fase pada Bidang $I_{b}-I_{v b}$ untuk $E_{3}$

Gambar 4 merupakan gambar grafik pada ruang dua dimensi dari populasi $I_{b}$ dan $I_{v b}$ pada model matematik ko-infeksi virus influenza A dan pneumokokus pada sel inang. Pada gambar terlihat bahwa untuk $t$ yang semakin besar maka solusi dari model khususnya $I_{b}$ dan $I_{v b}$ cenderung menuju ke suatu titik yang sama atau cenderung konvergen ke titik $\left(5.979 \times 10^{7}, 1.202 \times 10^{8}\right)$. Secara keseluruhan dinamika dari setiap subpopulasi pada model matematika ko-infeksi virus influenza A dan pneumokokus pada sel inang bergerak menuju titik setimbang endemik ko-infeksi $E_{3}=(22655,5.979 \times$ $\left.10^{7}, 5.2307 \times 10^{-5}, 1.202 \times 10^{8}, 2.29 \times 10^{8}, 1.4471 \times 10^{7}\right)$. Nilai $E_{3}$ diperoleh dengan mensubstitusikan nilai parameter pada Tabel 7 pada persamaan (1.a) - (1.f). Selain itu, berdasarkan nilai parameter yang diberikan pada Tabel 7 dapat diperoleh nilai $R_{0 v}>1$ dan $R_{0 b}>1$.

Berdasarkan hasil simulasi pada Gambar 4 diperoleh hasil bahwa titik setimbang endemik ko-infeksi pada model matematika ko-infeksi virus influenza A dan pneumokokus pada sel inang akan cenderung stabil asimtotis lokal jika memenuhi $R_{0 v}>1$ dan $R_{0 b}>1$. Hal ini merepresentasikan bahwa jika $R_{0 v}>1$, maka setiap sel yang terinfeksi virus influenza A dapat menularkan penyakit influenza A rata-rata lebih dari satu penderita baru atau dengan kata lain terjadi penyebaran penyakit influenza A. Jika $R_{0 b}>1$, maka setiap sel yang terinfeksi bakteri pneumokokus dapat menularkan penyakit pneumokokus rata-rata lebih dari satu penderita baru atau dengan kata lain terjadi penyebaran penyakit pneumokokus. Sehingga mengakibatkan terjadinya ko-infeksi. 


\section{$5 \quad$ Simulasi dan Interpretasi}

Simulasi numerik dilakukan dengan menggunakan software MATLAB 7.0 dengan nilai awal untuk setiap kondisi adalah $S=4 \times 10^{1}, I_{b}=10^{4}, I_{v}=10^{3}, I_{v b}=10^{3}, B=1.6 \times$ $10^{3}, V=2 \times 10^{7}$ untuk kondisi non endemik dan $S=4 \times 10^{8}, I_{b}=10^{5}, I_{v}=$ $10^{2}, I_{v b}=10^{3}, B=1.6 \times 10^{3}, V=10^{5}$ untuk kondisi endemik.

Kondisi non endemik ko-infeksi terjadi ketika tidak ada penyebaran penyakit, baik virus influenza A maupun bakteri pneumokokus, yang dapat dinyatakan dengan $R_{0 v}<1$ dan $R_{0 b}<1$. Simulasi dilakukan untuk $t=0$ sampai dengan $t=50$ hari. Nilai parameter yang digunakan untuk simulasi numerik tertera pada Tabel 8.

Tabel 8. Nilai Parameter untuk Simulasi Numerik Titik Setimbang $E_{0}$

\begin{tabular}{|c|c|c|c|}
\hline Parameter & Nilai & Satuan & Sumber \\
\hline $\bar{\Lambda}$ & $6.25 \times 10^{4}$ & sel.hari ${ }^{-1}$ & Mbabazi dkk. \\
\hline$\beta_{1}$ & $1.2 \times 10^{-5}$ & sel $^{-1} \cdot$ hari $^{-1}$ & Mbabazi dkk. \\
\hline$\beta_{2}$ & $2.7 \times 10^{-5}$ & sel $^{-1} \cdot$ hari $^{-1}$ & Mbabazi dkk. \\
\hline$\beta_{3}$ & $7.3 \times 10^{-8}$ & sel $^{-1} \cdot$ hari $^{-1}$ & Mbabazi dkk. \\
\hline$\beta_{4}$ & $4.1 \times 10^{-6}$ & $\mathrm{sel}^{-1} \cdot \mathrm{hari}^{-1}$ & Mbabazi dkk. \\
\hline$\mu_{1}$ & $6.25 \times 10^{-1}$ & $h_{a r i}{ }^{-1}$ & Mbabazi dkk. \\
\hline$\mu_{2}$ & $1.34 \times 10^{-6}$ & $h_{a r i}{ }^{-1}$ & Asumsi \\
\hline$\mu_{3}$ & $8.9 \times 10^{-1}$ & hari $^{-1}$ & Mbabazi dkk. \\
\hline$\mu_{4}$ & $5.2 \times 10^{-1}$ & $h_{a r i}{ }^{-1}$ & Asumsi \\
\hline$\tau_{1}$ & $1.102 \times 10^{-8}$ & hari $^{-1}$ & Asumsi \\
\hline$\tau_{2}$ & $8.6 \times 10^{-2}$ & hari $^{-1}$ & Asumsi \\
\hline$\tau_{3}$ & $2.4 \times 10^{-3}$ & $h{ }^{-1}$ & Asumsi \\
\hline$n_{1}$ & $1 \times 10^{3}$ & hari $^{-1}$ & Mbabazi dkk. \\
\hline$n_{2}$ & $10^{5}$ & hari $^{-1}$ & Asumsi \\
\hline$n_{3}$ & $2.51 \times 10^{1}$ & hari $^{-1}$ & Mbabazi dkk. \\
\hline$\alpha_{1}$ & $3.2 \times 10^{-4}$ & hari $^{-1}$ & Mbabazi dkk. \\
\hline$\alpha_{2}$ & $10^{-3}$ & hari $^{-1}$ & Mbabazi dkk. \\
\hline$\delta_{1}$ & $2 \times 10^{-5}$ & hari $^{-1}$ & Mbabazi dkk. \\
\hline$\delta_{2}$ & 0.5 & hari $^{-1}$ & Mbabazi dkk. \\
\hline$r$ & $2.7 \times 10^{1}$ & $h_{a r i}{ }^{-1}$ & Mbabazi dkk. \\
\hline$K$ & $2.3 \times 10^{8}$ & $C F U$ & Mbabazi dkk. \\
\hline$\gamma$ & $8.877 \times 10^{-1}$ & sel $^{-1} \cdot$ hari $^{-1}$ & Mbabazi dkk. \\
\hline$m$ & 60 & $(C F U / m l) \mathrm{sel}^{-1}$ & Asumsi \\
\hline$h$ & 5 & jam & Mbabazi dkk. \\
\hline$A$ & $10^{5.5}$ & sel & Mbabazi dkk. \\
\hline
\end{tabular}


Berdasarkan nilai parameter pada Tabel 8 diperoleh nilai $R_{0 v}=\frac{\beta_{2} \tau_{2} n_{2}}{\mu_{3}\left(\alpha_{1}+\delta_{2}\right)}=0.5215<1$ dan $R_{0 b}=\frac{\beta_{1} \Lambda \tau_{1} n_{1}}{\mu_{1} \mu_{2}\left(\alpha_{2}+\delta_{1}+\gamma m-r\right)}=0.3758<1$. Berikut adalah hasil simulasi untuk populasi sel, populasi bakteri pneumokokus dan populasi virus influenza $\mathrm{A}$
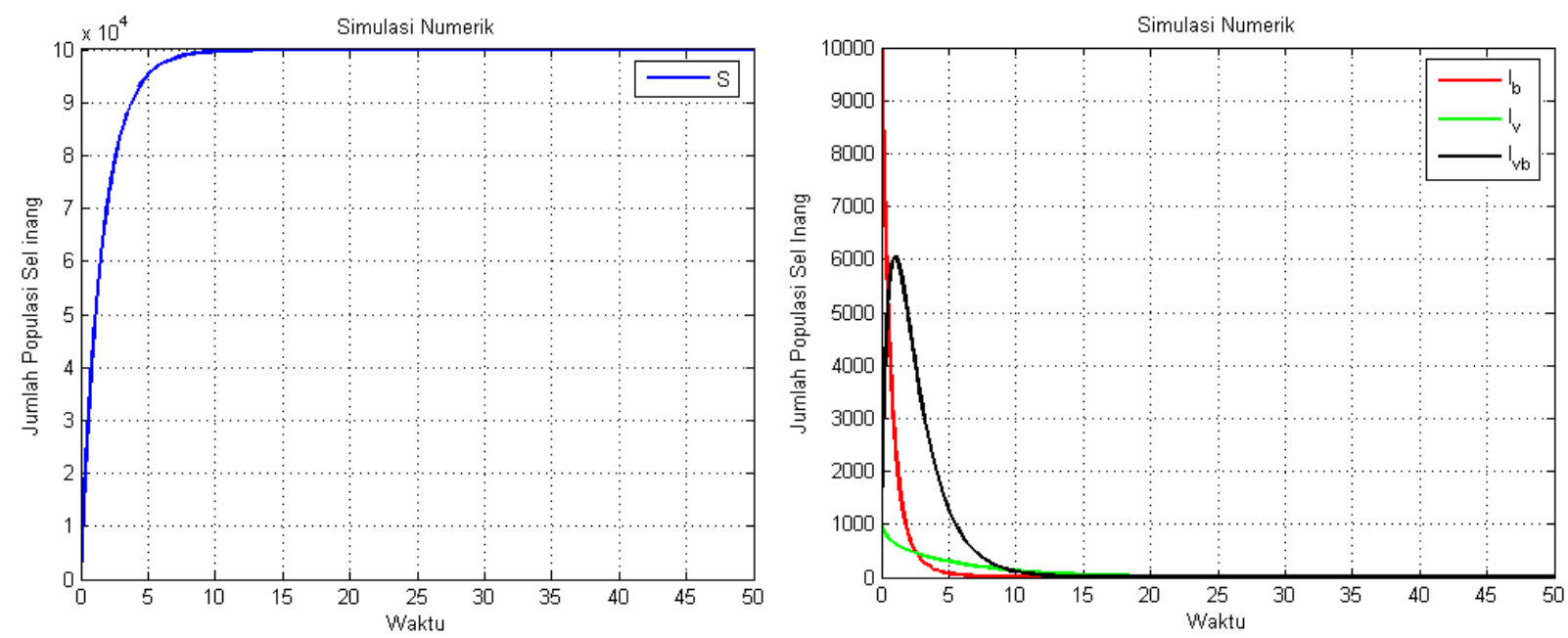

Gambar 5. Dinamika Populasi Sel Saat $R_{0 v}<1$ dan $R_{0 b}<1$

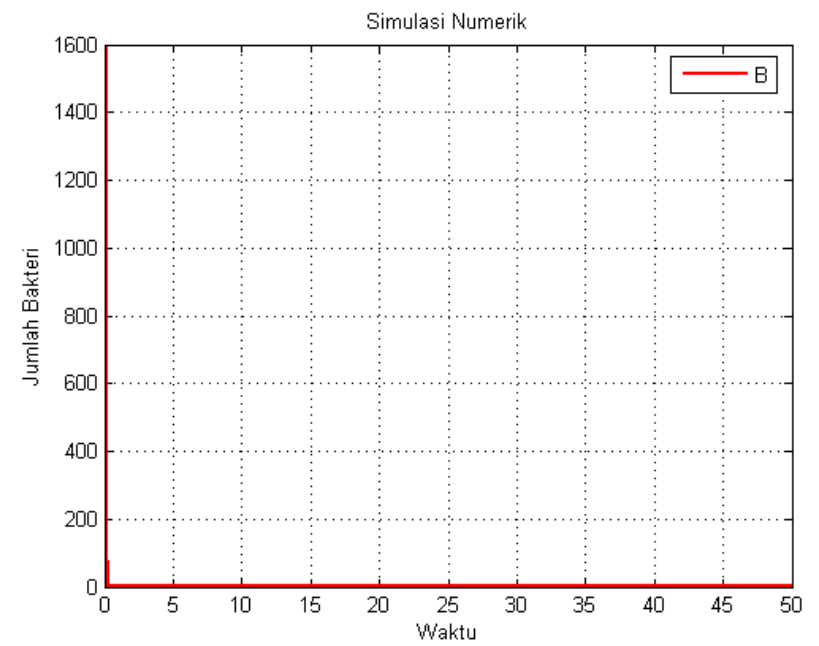

Gambar 6. Dinamika Populasi Bakteri Saat $R_{0 v}<1$ dan $R_{0 b}<1$ 


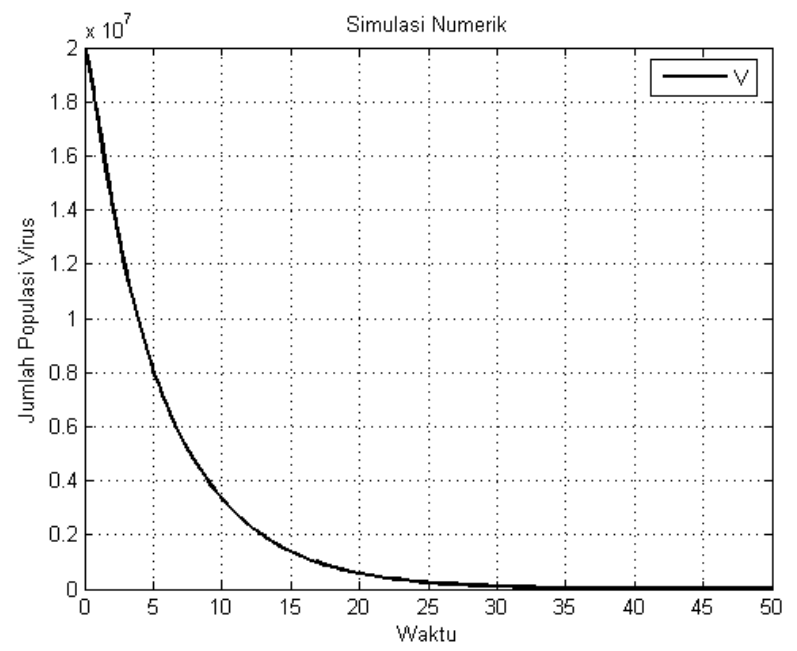

Gambar 7. Dinamika Populasi Virus Saat $R_{0 v}<1$ dan $R_{0 b}<1$

Gambar 5-7 merupakan hasil simulasi pada populasi sel, populasi bakteri pneumokokus dan populasi virus influenza A ketika tidak ada penyebaran penyakit influenza A dan pneumokokus. Jumlah populasi sel yang terinfeksi virus influenza A, sel yang terinfeksi pneumokokus, sel yang terkena ko-infeksi, virus influenza A dan bakteri pneumokokus dalam jangka waktu tertentu bergerak menuju nol atau mengalami kepunahan. Sedangkan populasi sel yang rentan mengalami kenaikan sampai hari ke-10 kemudian konstan.

Kondisi endemik ko-infeksi terjadi ketika terdapat penyebaran penyakit influenza A dan pneumokokus secara bersamaan, yang dapat dinyatakan dengan $R_{0 v}>1$ dan $R_{0 b}>1$. Simulasi dilakukan untuk $t=0$ sampai dengan $t=50$ hari. Nilai awal dan parameter yang digunakan untuk simulasi numerik tertera pada Tabel 2.6 dan Tabel 2.7. berdasarkan nilai parameter tersebut diperoleh nilai $R_{0 v}=\frac{\beta_{2} \tau_{2} n_{2}}{\mu_{3}\left(\alpha_{1}+\delta_{2}\right)}=5.2146>1$ dan $R_{0 b}=$ $\frac{\beta_{1} \Lambda \tau_{1} n_{1}}{\mu_{1} \mu_{2}\left(\alpha_{2}+\delta_{1}+\gamma m-r\right)}=3.7576 \times 10^{9}>1$. Berikut adalah hasil simulasi untuk populasi sel, populasi bakteri pneumokokus dan populasi virus influenza $\mathrm{A}$ 


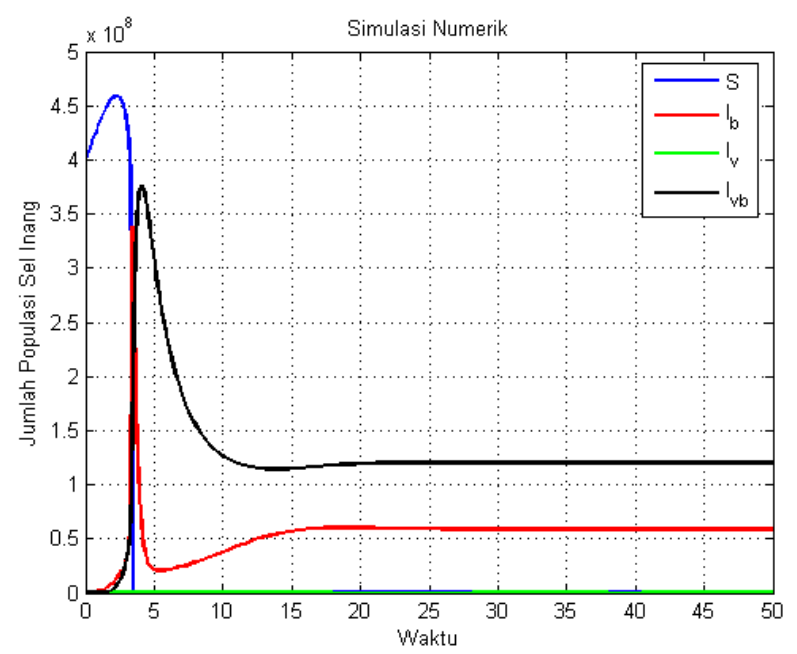

Gambar 8. Dinamika Populasi Sel Saat $R_{0 v}>1$ dan $R_{0 b}>1$

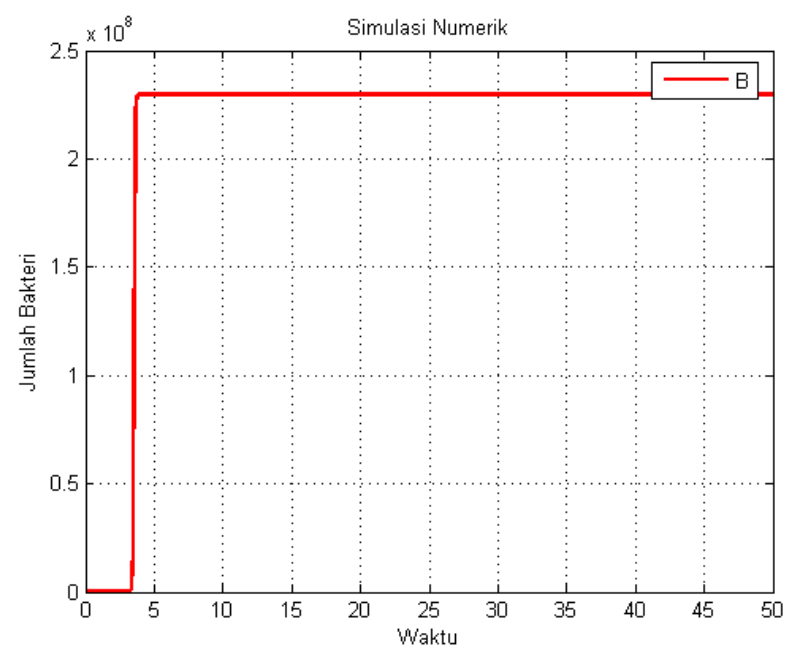

Gambar 9. Dinamika Populasi Bakteri Saat $R_{0 v}>1$ dan $R_{0 b}>1$ 


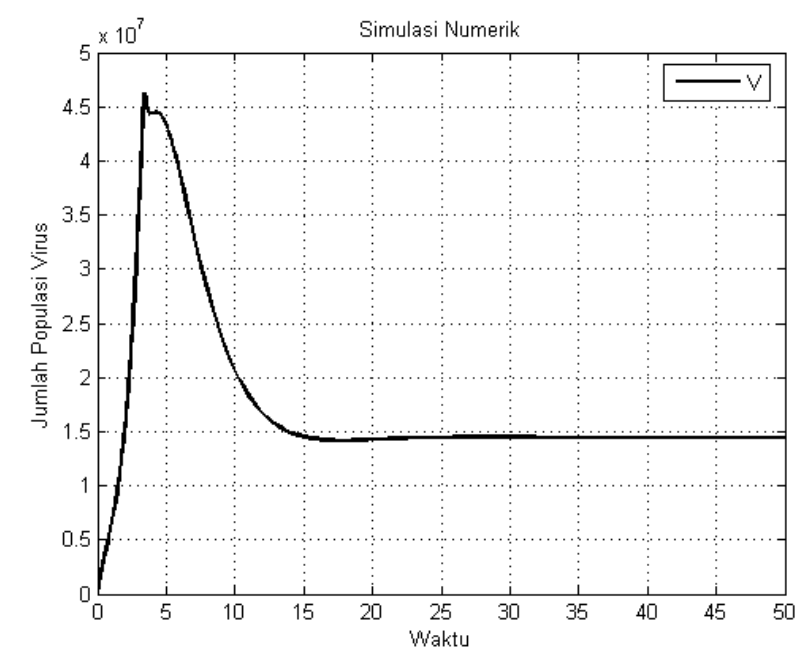

Gambar 10. Dinamika Populasi Virus Saat $R_{0 v}>1$ dan $R_{0 b}>1$

Gambar 8 - 10 merupakan hasil simulasi pada populasi sel, populasi bakteri pneumokokus dan populasi virus influenza A ketika terjadi penyebaran penyakit influenza A dan pneumokokus secara bersamaan. Jumlah populasi sel yang terinfeksi pneumokokus dan sel yang terkena ko-infeksi mengalami kenaikan sampai hari ke-4 kemudian sedikit turun sampai hari ke-20 dan kemudian konstan. Jumlah populasi bakteri pneumokokus juga mengalami kenaikan pada hari ke-4 kemudian konstan. Jumlah populasi virus influenza A mengalami kenaikan sampai hari ke-3 kemudian turun drastis pada hari ke-4 dikarenakan jumlah populasi sel yang terinfeksi virus influenza A juga mengalami penurunan drastis pada waktu yang sama sampai hari ke-20 kemudian konstan. Sedangkan populasi sel yang rentan dalam jangka waktu tertentu bergerak menuju nol atau mengalami kepunahan.

\section{Analisis Sensitivitas Parameter}

Analisis sensitivitas bertujuan untuk menentukan parameter yang memiliki pengaruh besar pada syarat kestabilan dari titik setimbang non endemik maupun endemik. Hal tersebut dapat diketahui melalui indeks sensitivitas $\left(e_{n}\right)$ dari masing-masing parameter. Adapun indeks sensitivitas parameter dirumuskan sebagai berikut [12]:

dengan :

$$
e_{n}=\left(\frac{\partial R_{0}}{\partial n}\right) \frac{n}{R_{0}}
$$

$n$ : parameter yang akan dianalisis

$e_{n}$ : indeks sensitivitas parameter $n$. 
Pada penelitian initelah diperoleh nilai $R_{0}$, yaitu

$$
\begin{gathered}
R_{0 v}=\frac{\beta_{2} \tau_{2} n_{2}}{\mu_{3}\left(\alpha_{1}+\delta_{2}\right)^{\prime}} \\
R_{0 b}=\frac{\beta_{1} \Lambda \tau_{1} n_{1}}{\mu_{1} \mu_{2}\left(\alpha_{2}+\delta_{1}+\gamma m-r\right)},
\end{gathered}
$$

berdasarkan nilai $R_{0 v}$ dan $R_{0 b}$ yang telah diperoleh, pada $R_{0 v}$ terdapat enam parameter yang akan ditentukan indeks sensitivitasnya, yaitu $\beta_{2}, \tau_{2}, n_{2}, \mu_{3}, \alpha_{1}$ dan $\delta_{2}$. Sedangkan pada $R_{0 b}$ terdapat sebelas parameter yang akan ditentukan indeks sensitivitasnya, yaitu $\Lambda, \beta_{1}, \tau_{1}, n_{1}, \mu_{1}, \mu_{2}, \alpha_{2}, \delta_{1}, r, \gamma$ dan $m$. Berikut adalah contoh perhitungan indeks sensitivitas untuk parameter $\mu_{1}$.

$$
e_{\mu_{1}}=\frac{\partial R_{0 b}}{\partial \mu_{1}} \frac{\mu_{1}}{R_{0 b}}=-\frac{\beta_{1} \Lambda \tau_{1} n_{1}}{\mu_{1}{ }^{2} \mu_{2}\left(\alpha_{2}+\delta_{1}+\gamma m-r\right)} \frac{\mu_{1}}{\frac{\beta_{1} \Lambda \tau_{1} n_{1}}{\mu_{1} \mu_{2}\left(\alpha_{2}+\delta_{1}+\gamma m-r\right)}}=-1,
$$

Hasil perhitungan indeks sensitivitas parameter pada model matematika ko-infeksi virus influenza A dan pneumokokus pada sel inang disajikan dalam Tabel 9 dan Tabel 10 sebagai berikut:

Tabel 9. Hasil Perhitungan Indeks Sensitivitas Parameter $R_{0 v}$

\begin{tabular}{|c|c|}
\hline Parameter & Indeks Sensitivitas \\
\hline$\beta_{2}$ & 1 \\
\hline$\tau_{2}$ & 1 \\
\hline$n_{2}$ & 1 \\
\hline$\mu_{3}$ & -0.99 \\
\hline$\alpha_{1}$ & -0.0006 \\
\hline$\delta_{2}$ & -0.99 \\
\hline
\end{tabular}

Tabel 10. Hasil Perhitungan Indeks Sensitivitas Parameter $R_{0 b}$

\begin{tabular}{|c|c|}
\hline Parameter & Indeks Sensitivitas \\
\hline$\Lambda$ & 1 \\
\hline$\beta_{1}$ & 1 \\
\hline$\tau_{1}$ & 1 \\
\hline$n_{1}$ & 1 \\
\hline$\mu_{1}$ & -1 \\
\hline$\mu_{2}$ & -1 \\
\hline$\alpha_{2}$ & -0.0003 \\
\hline$\delta_{1}$ & -0.0000007 \\
\hline$\gamma$ & -2.02 \\
\hline$m$ & -2.02 \\
\hline$r$ & 1.02 \\
\hline
\end{tabular}


Indeks sensitivitas positif menunjukkan bahwa jika nilai suatu parameter bertambah maka nilai $R_{0 v}$ dan $R_{0 b}$ juga akan bertambah. Sedangkan apabila indeks sensitivitasnya negatif menunjukkan bahwa jika nilai suatu parameter bertambah mengakibatkan nilai $R_{0 v}$ dan $R_{0 b}$ akan berkurang. Berdasarkan Tabel 2.9 dan Tabel 2.10 dapat diketahui bahwa indeks sensitivitas dari $r$ adalah 1.02, maka dapat diinterpretasikan bahwa jika laju pertumbuhan maksimum pneumokokus $(r)$ bertambah sebesar $10 \%$, maka nilai $R_{0 b}$ akan bertambah sebesar $10.2 \%$ dan begitu pula sebaliknya. Analisis tersebut juga berlaku pada parameter $\beta_{2}, \tau_{2}, n_{2}, \Lambda, \beta_{1}, \tau_{1}$ dan $n_{1}$. Sedangkan apabila laju kematian alami sel yang terinfeksi virus influenza A $\left(\mu_{3}\right)$ bertambah $10 \%$ maka nilai $R_{0 v}$ akan berkurang 9.9\%. Analisis tersebut juga berlaku pada parameter $\mu_{1}, \mu_{2}, \alpha_{1}, \alpha_{2}, \delta_{1}, \delta_{2}, \gamma$ dan $m$. Dari uraian tersebut dapat disimpulkan bahwa parameter yang memiliki pengaruh besar pada model matematika ko-infeksi virus influenza $\mathrm{A}$ dan pneumokokus pada sel inang untuk $R_{0 v}$ adalah $\beta_{2}, \tau_{2}, n_{2}$ dan untuk $R_{0 b}$ adalah $\gamma$ dan $m$.

Dikarenakan parameter $n_{2}$ adalah jumlah infeksi partikel virus influenza $A$ yang dibebaskan dari lisis sel yang terinfeksi virus influenza $A$, sehingga tidak bisa untuk dikontrol. Selanjutnya akan dilakukan simulasi sensitivitas parameter $\beta_{2}$ dan $\tau_{2}$ terhadap $R_{0 v}$ yang masing masing-masing merupakan laju sel inang yang terinfeksi oleh virus influenza A dan laju pelepasan oleh sel yang terinfeksi virus influenza A. Kemudian parameter $\gamma$ dan $m$ terhadap $R_{0 b}$ yang masing-masing merupakan laju fagositosis dan jumlah maksimal makrofag alveolar dapat tertangkap. Pada simulasi pertama untuk $R_{0 v}$, dipilih nilai $\beta_{2}=2.7 \times 10^{-4}, \beta_{2}=2.7 \times 10^{-5}$ dan $\beta_{2}=2.7 \times 10^{-6}$, sedangkan nilai $\tau_{2}$ berada pada interval $1 \times 10^{-1}<\tau_{2}<2 \times 10^{-1}$. Simulasi kedua untuk $R_{0 v}$, dipilih $\tau_{2}=8.6 \times 10^{-0.8}, \tau_{2}=8.6 \times 10^{-1}$ dan $\tau_{2}=8.6 \times 10^{-2}$, sedangkan nilai $\beta_{2}$ berada pada interval $1 \times 10^{-5}<\beta_{2}<2 \times 10^{-5}$. Pada simulasi pertama untuk $R_{0 b}$, dipilih nilai $m=40, m=60$ dan $m=80$, sedangkan nilai $\gamma$ berada pada interval $2 \times 10^{-1}<\gamma<$ $9 \times 10^{-1}$. Simulasi kedua untuk $R_{0 b}$, dipilih $\gamma=7.877 \times 10^{-1}, \gamma=8.877 \times 10^{-1}$ dan $\gamma=9.877 \times 10^{-1}$, sedangkan nilai $\beta_{1}$ berada pada interval $55<m<65$. Adapun hasil simulasi berupa grafik sensitivitas $\beta_{2}$ dan $\tau_{2}$ terhadap $R_{0 v}, \gamma$ dan $m$ terhadap $R_{0 b}$ dapat dilihat pada Gambar 11 - 14 berikut: 


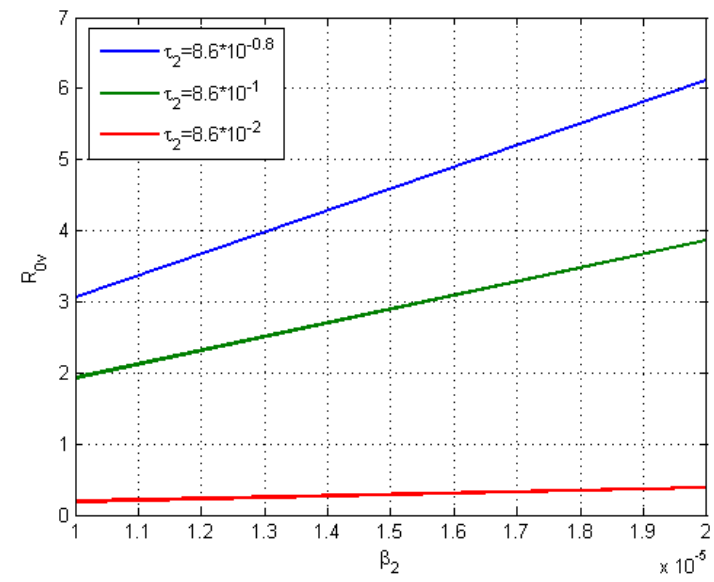

Gambar 11. Sensitivitas $\beta_{2}$ Terhadap $R_{0 v}$ dengan Tiga Nilai $\tau_{2}$ Berbeda

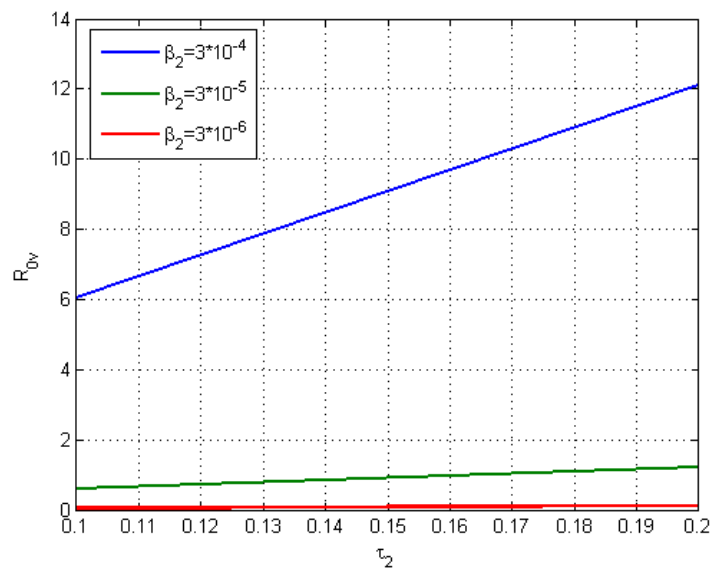

Gambar 12. Sensitivitas $\tau_{2}$ Terhadap $R_{0 v}$ dengan Tiga Nilai $\beta_{2}$ Berbeda

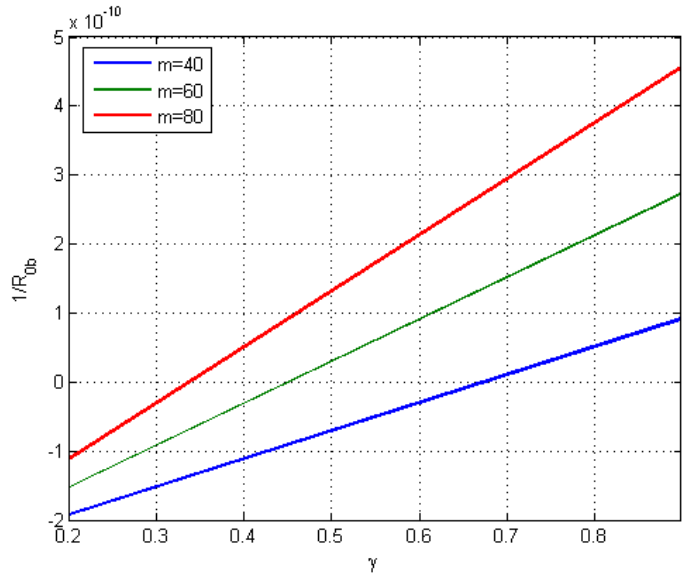

Gambar 13. Sensitivitas $\gamma$ Terhadap $R_{0 b}$ dengan Tiga Nilai $m$ Berbeda 


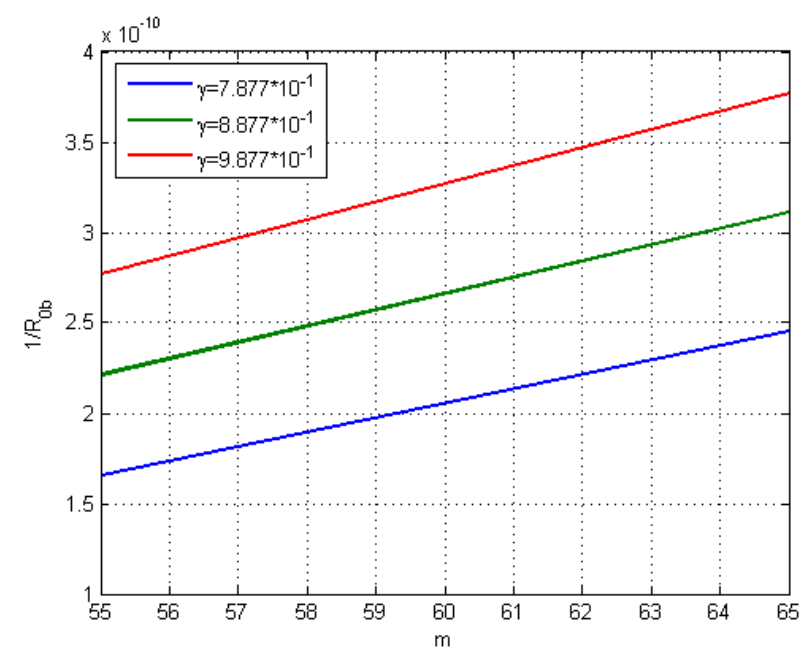

Gambar 14. Sensitivitas $m$ Terhadap $R_{0 b}$ dengan Tiga Nilai $\gamma$ Berbeda

Gambar 11 dan 12 menunjukkan bahwa jika laju sel inang yang terinfeksi oleh virus influenza $\mathrm{A}\left(\beta_{2}\right)$ dan laju pelepasan oleh sel yang terinfeksi virus influenza $\mathrm{A}\left(\tau_{2}\right)$ semakin besar, maka nilai $R_{0 v}$ juga akan semakin besar, artinya penyebaran virus influenza A akan semakin meluas. Sedangkan Gambar 13 dan 14 menunjukkan bahwa untuk ketiga nilai $\gamma$ dan $m$ yang berbeda, semakin besar nilai $\gamma$ dan $m$ maka semakin besar nilai $\frac{1}{R_{0 b}}$. Karena nilai $\frac{1}{R_{0 b}}$ semakin besar, maka nilai $R_{0 b}$ akan semakin kecil. Sehingga dapat diartikan bahwa jika laju fagositosis $(\gamma)$ dan jumlah maksimal makrofag alveolar dapat tertangkap $(m)$ semakin besar, maka nilai $R_{0 b}$ akan semakin kecil. Hal tersebut dikarenakan indeks sensitivitas dari parameter $\beta_{2}$ dan $\tau_{2}$ bernilai positif, sehingga ketika nilai parameter tersebut semakin besar maka nilai $R_{0 v}$ juga akan semakin besar. Sedangkan untuk indeks sensitivitas parameter $\gamma$ dan $m$ yang bernilai negatif, maka ketika nilai parameternya semakin besar mengakibatkan nilai $R_{0 b}$ akan semakin kecil.

\section{$7 \quad$ Kesimpulan}

Berdasarkan hasil pembahasan yang telah dijelaskan pada bab sebelumnya, maka dapat disimpulkan bahwa:

1. Model matematika ko-infeksi virus influenza A dan pneumokokus pada sel inang memiliki empat titik setimbang, yaitu titik setimbang non endemik ko-infeksi $\left(E_{0}\right)$, titik setimbang endemik virus influenza $\mathrm{A}\left(E_{1}\right)$, titik setimbang endemik pneumokokus $\left(E_{2}\right)$ dan titik setimbang endemik ko-infeksi $\left(E_{3}\right)$. Titik setimbang non endemic ko-infeksi akan stabil asimtotis jika $R_{0 v}<1, R_{0 b}<1$ dan memenuhi beberapa kondisi. Titik setimbang endemik virus influenza A akan cenderung stabil asimtotis lokal jika $R_{0 v}>1$ dan $R_{0 b}<1$. Titik setimbang endemik pneumokokus 
akan cenderung stabil asimtotis lokal jika $R_{0 v}<1$ dan $R_{0 b}>1$. Titik setimbang endemik ko-infeksi akan cenderung stabil asimtotis lokal jika $R_{0 v}>1$ dan $R_{0 b}>1$, dengan nilai $R_{0 v}$ dan $R_{0 b}$ sebagai berikut:

$$
R_{0 v}=\frac{\beta_{2} \tau_{2} n_{2}}{\mu_{3}\left(\alpha_{1}+\delta_{2}\right)}, \quad R_{0 b}=\frac{\beta_{1} \Lambda \tau_{1} n_{1}}{\mu_{1} \mu_{2}\left(\alpha_{2}+\delta_{1}+\gamma m-r\right)} .
$$

2. Berdasarkan hasil simulasi numerik menunjukkan bahwa kenaikan jumlah populasi virus influenza A dan jumlah populasi pneumokokus mengakibatkan jumlah populasi sel yang terinfeksi virus influenza A dan pneumokokus (ko-infeksi) juga mengalami kenaikan.

\section{$8 \quad$ Saran}

Pada penelitian selanjutnya dapat dilakukan estimasi parameter untuk model matematika ko-infeksi virus influenza A dan pneumokokus pada sel inang dengan data yang ada di Indonesia. Dengan demikian model matematika ko-infeksi virus influenza A dan pneumokokus pada sel inang dapat digunakan untuk memprediksi penyebaran ko-infeksi virus influenza A dan pneumokokus pada sel inang di Indonesia.

\section{Daftar Pustaka}

[1] Asaduzzaman S. M., Ma J., dan Driessche P. V. D., 2015, The coexistence or replacement of two subtypes of influenza, Mathematical Biosience, 270: 1-9.

[2] Khanh N. H., 2016, Stability analysis of an influenza virus model with disease resistance, Journal of the Egyptian Mathematical Society, 24:193-199.

[3] WHO, 2018, Influenza (Seasonal), di https://www.who.int/en/news-room/factsheets/detail/influenza-(seasonal) (diakses pada 5 April 2019).

[4] Lamb K. E., Greenhalgh D., dan Robertson C., 2011, A Simple mathematical model for genetic effect in pneumococcal carriage and transmission, Journal of Computation and Applied Mathematics, 235:1812-1818.

[5] Rudd J.M., Ashar H. K., Chow V. TK., dan Teluguakula N., 2016, Lethal synergism between influenza and Streptococcus pneumoniae, J Infect Pulm Dis, 2(2):1-13.

[6] Gupta R.K., George R., dan Nguyen-Van-Tam J. S., 2008, Bacterial pneumonia and pandemic influenza planning, Emerging Infectious Diseases, 14(8):1187-1192.

[7] American Lung Association (ALA), 2015, Trends in pneumonia and influenza morbidity and mortality, [Internet], Tersedian di: https://www.lung.org/assets/documents/research/pi-trend-report.pdf.

[8] Crowe S., Utley M.,Walker G., Grove P., dan Pagel C., 2011, A model to evaluate mass vaccination against pneumococcus as a countermeasure against pandemic influenza, Vaccine, 29:5065-5077.

[9] Cheng Y-H., You S-H., Lin Y-J., Chen S-C., Chen W-Y., Chou W-C., Hsieh N-H., dan Liao C-M., 2017, Mathematical modelling of postcoinfection with influenza A 
virus and strepcococcus pneumoniae, with implications for pneumonia and COPDrisk assessment, International Journal of COPD, 12:1973-1988.

[10] Mbabazi F. K., Mugisha J.Y.T., dan Kimathi M., 2018, Modelling the within-host co-infection of influenza A virus and pneumococcus, Applied Mathematics and Computation, 339:488-506.

[11] Driessche P. van den, dan Watmough J., 2002, Reproduction numbers and subthreshold endemic equilibria for compartmental models of disease transmission, Mathematical Biosciences, 180:29-48.

[12] Chitnis, N., Hyman, J.M., dan Cushing, 2008, Determine important parameters in the spread of malaria through the sensitivity analysis of mathematics model, Bulletin of Mathematical Biology, 70:1272-1296. 